\title{
Adhesion Class GPCRs in GtoPdb v.2021.3
}

Demet Arac-Ozkan ${ }^{1}$, Gabriela Aust ${ }^{2}$, Tom I. Bonner ${ }^{3}$, Heike Cappallo-Obermann ${ }^{4}$, Caroline Formstone $^{5}$, Jörg Hamann ${ }^{6}$, Breanne Harty ${ }^{7}$, Henrike Heyne ${ }^{2}$, Christiane Kirchhoff ${ }^{4}$, Barbara Knapp ${ }^{8}$, Arunkumar Krishnan ${ }^{9}$, Tobias Langenhan ${ }^{2}$, Diana Le Duc ${ }^{2}$, Hsi-Hsien Lin ${ }^{10}$, David C. Martinelli ${ }^{11}$, Kelly Monk ${ }^{7}$, Xianhua Piao ${ }^{12}$, Simone Prömel ${ }^{2}$, Torsten Schöneberg ${ }^{2}$, Helgi Schiöth ${ }^{13}$, Kathleen Singer ${ }^{12}$, Martin Stacey ${ }^{14}$, Yuri Ushkaryov ${ }^{15}$, Uwe Wolfrum ${ }^{8}$ and Lei Xu ${ }^{16}$

1. University of Chicago, USA

2. University of Leipzig, Germany

3. National Institute of Mental Health, USA

4. University of Hamburg, Germany

5. King's College London, UK

6. University of Amsterdam, The Netherlands

7. Washington University, USA

8. Johannes-Gutenberg Universitaet Mainz, Germany

9. Uppsala Universitet, Sweden

10. Chang Gung University, Taiwan

11. Stanford University, USA

12. Boston Children's Hospital, USA

13. Uppsala University, Sweden

14. University of Leeds, UK

15. University of Kent, UK

16. University of Rochester, USA

\begin{abstract}
Adhesion GPCRs are structurally identified on the basis of a large extracellular region, similar to the Class B GPCR, but which is linked to the 7TM region by a GPCR autoproteolysis-inducing (GAIN) domain [9] containing a GPCR proteolytic site. The N-terminus often shares structural homology with adhesive domains (e.g. cadherins, immunolobulin, lectins) facilitating inter- and matricellular interactions and leading to the term adhesion GPCR [101, 403]. Several receptors have been suggested to function as mechanosensors [309, 280, 383, 35]. The nomenclature of these receptors was revised in 2015 as recommended by NC-IUPHAR and the Adhesion GPCR Consortium [122].
\end{abstract}

\section{Contents}

This is a citation summary for Adhesion Class GPCRs in the Guide to Pharmacology database (GtoPdb). It exists purely as an adjunct to the database to facilitate the recognition of citations to and from the database by citation analyzers. Readers will almost certainly want to visit the relevant sections of the database which are given here under database links.

GtoPdb is an expert-driven guide to pharmacological targets and the substances that act on them. GtoPdb is a reference work which is most usefully represented as an on-line database. As in any publication this work should be appropriately cited, and the papers it cites should also be recognized. This document provides a citation for the relevant parts of the database, and also provides a reference list for the research cited by those parts. For further details see [39].

Please note that the database version for the citations given in GtoPdb are to the most recent preceding version in which the family or its subfamilies and targets were substantially changed. The links below are to the current version. If you need to consult the cited version, rather than the most recent version, please contact the GtoPdb curators.

\section{Database links}


Adhesion Class GPCRs

https://www.guidetopharmacology.org/GRAC/FamilyDisplayForward?familyId=17

Introduction to Adhesion Class GPCRs

https://www.guidetopharmacology.org/GRAC/FamilyIntroductionForward?familyId=17

\section{Receptors}

\section{ADGRA1}

https://www.guidetopharmacology.org/GRAC/ObjectDisplayForward?objectId=197 ADGRA2

https://www.guidetopharmacology.org/GRAC/ObjectDisplayForward?objectId=198 ADGRA3

https://www.guidetopharmacology.org/GRAC/ObjectDisplayForward?objectId=199 ADGRB1

https://www.guidetopharmacology.org/GRAC/ObjectDisplayForward?objectId=174 ADGRB2

https://www.guidetopharmacology.org/GRAC/ObjectDisplayForward?objectId=175 ADGRB3

https://www.guidetopharmacology.org/GRAC/ObjectDisplayForward?objectId=176 CELSR1

https://www.guidetopharmacology.org/GRAC/ObjectDisplayForward?objectId=178 CELSR2

https://www.guidetopharmacology.org/GRAC/ObjectDisplayForward?objectId=179 CELSR3

https://www.guidetopharmacology.org/GRAC/ObjectDisplayForward?objectId=180 ADGRD1

https://www.guidetopharmacology.org/GRAC/ObjectDisplayForward?objectId=202 ADGRD2

https://www.guidetopharmacology.org/GRAC/ObjectDisplayForward?objectId=204 ADGRE1

https://www.guidetopharmacology.org/GRAC/ObjectDisplayForward?objectId=182 ADGRE2

https://www.guidetopharmacology.org/GRAC/ObjectDisplayForward?objectId=183 ADGRE3

https://www.guidetopharmacology.org/GRAC/ObjectDisplayForward?objectId=184 ADGRE4P

https://www.guidetopharmacology.org/GRAC/ObjectDisplayForward?objectId=185 ADGRE5

https://www.guidetopharmacology.org/GRAC/ObjectDisplayForward?objectId=177 ADGRF1

https://www.guidetopharmacology.org/GRAC/ObjectDisplayForward?objectId=190 ADGRF2

https://www.guidetopharmacology.org/GRAC/ObjectDisplayForward?objectId=191 ADGRF3

https://www.guidetopharmacology.org/GRAC/ObjectDisplayForward?objectId=193 ADGRF4

https://www.guidetopharmacology.org/GRAC/ObjectDisplayForward?objectId=195 ADGRF5

https://www.guidetopharmacology.org/GRAC/ObjectDisplayForward?objectId=196 ADGRG1

https://www.guidetopharmacology.org/GRAC/ObjectDisplayForward?objectId=186 ADGRG2

https://www.guidetopharmacology.org/GRAC/ObjectDisplayForward?objectId=187 ADGRG3

https://www.guidetopharmacology.org/GRAC/ObjectDisplayForward?objectId=188 ADGRG4

https://www.guidetopharmacology.org/GRAC/ObjectDisplayForward?objectId=192 ADGRG5

https://www.guidetopharmacology.org/GRAC/ObjectDisplayForward?objectId=194 ADGRG6

https://www.guidetopharmacology.org/GRAC/ObjectDisplayForward?objectId=200 ADGRG7

https://www.guidetopharmacology.org/GRAC/ObjectDisplayForward?objectId=201 ADGRL1

https://www.guidetopharmacology.org/GRAC/ObjectDisplayForward?objectId=206 ADGRL2

https://www.guidetopharmacology.org/GRAC/ObjectDisplayForward?objectId=207 ADGRL3

https://www.guidetopharmacology.org/GRAC/ObjectDisplayForward?objectId=208 


\section{ADGRL4}

https://www.guidetopharmacology.org/GRAC/ObjectDisplayForward?objectId=181

ADGRV1

https://www.guidetopharmacology.org/GRAC/ObjectDisplayForward?objectId=189

\section{References}

1. Aalto Y, El-Rifa W, Vilpo L, Ollila J, Nagy B, Vihinen M, Vilpo J and Knuutila S. (2001) Distinct gene expression profiling in chronic lymphocytic leukemia with 11q23 deletion. Leukemia 15: 1721-8 [PMID:11681413]

2. Abe J, Suzuki H, Notoya M, Yamamoto T and Hirose S. (1999) Ig-hepta, a novel member of the G protein-coupled hepta-helical receptor (GPCR) family that has immunoglobulin-like repeats in a long N-terminal extracellular domain and defines a new subfamily of GPCRs. J Biol Chem 274: 19957-64 [PMID:10391944]

3. Ackerman SD, Luo R, Poitelon Y, Mogha A, Harty BL, D'Rozario M, Sanchez NE, Lakkaraju AKK, Gamble P and Li J et al.. (2018) GPR56/ADGRG1 regulates development and maintenance of peripheral myelin. J Exp Med 215: 941-961 [PMID:29367382]

4. Akashi K, He X, Chen J, Iwasaki H, Niu C, Steenhard B, Zhang J, Haug J and Li L. (2003) Transcriptional accessibility for genes of multiple tissues and hematopoietic lineages is hierarchically controlled during early hematopoiesis. Blood 101: 383-9 [PMID:12393558]

5. Allache R, De Marco P, Merello E, Capra V and Kibar Z. (2012) Role of the planar cell polarity gene CELSR1 in neural tube defects and caudal agenesis. Birth Defects Res Part A Clin Mol Teratol 94: 176-81 [PMID:22371354]

6. Anderson KD, Pan L, Yang XM, Hughes VC, Walls JR, Dominguez MG, Simmons MV, Burfeind P, Xue Y and Wei Y et al.. (2011) Angiogenic sprouting into neural tissue requires Gpr124, an orphan G protein-coupled receptor. Proc Natl Acad Sci USA 108: 2807-12 [PMID:21282641]

7. Antoni G, Morange PE, Luo Y, Saut N, Burgos G, Heath S, Germain M, Biron-Andreani C, Schved JF and Pernod G et al.. (2010) A multi-stage multi-design strategy provides strong evidence that the BAI3 locus is associated with early-onset venous thromboembolism. J Thromb Haemost $\mathbf{8}$ : 2671-9 [PMID:20946148]

8. Araç D, Aust G, Calebiro D, Engel FB, Formstone C, Goffinet A, Hamann J, Kittel RJ, Liebscher I and Lin $\mathrm{HH}$ et al.. (2012) Dissecting signaling and functions of adhesion $\mathrm{G}$ protein-coupled receptors. Ann N Y Acad Sci 1276: 1-25 [PMID:23215895]

9. Araç D, Boucard AA, Bolliger MF, Nguyen J, Soltis SM, Südhof TC and Brunger AT. (2012) A novel evolutionarily conserved domain of cell-adhesion GPCRs mediates autoproteolysis. EMBO J 31: 1364-78 [PMID:22333914]

10. Arcos-Burgos M, Jain M, Acosta MT, Shively S, Stanescu H, Wallis D, Domené S, Vélez JI, Karkera JD and Balog J et al.. (2010) A common variant of the latrophilin 3 gene, LPHN3, confers susceptibility to ADHD and predicts effectiveness of stimulant medication. Mol Psychiatry 15: 1053-66 [PMID:20157310]

11. Ashton AC, Volynski KE, Lelianova VG, Orlova EV, Van Renterghem C, Canepari M, Seagar M and Ushkaryov YA. (2001) alpha-Latrotoxin, acting via two Ca2+-dependent pathways, triggers exocytosis of two pools of synaptic vesicles. J Biol Chem 276: 44695-703 [PMID:11572875]

12. Aust G. (2010) Adhesion-GPCRS in tumorigenesis. Adv Exp Med Biol 706: 109-20 [PMID:21618830]

13. Aust G, Eichler W, Laue S, Lehmann I, Heldin NE, Lotz O, Scherbaum WA, Dralle H and HoangVu C. (1997) CD97: a dedifferentiation marker in human thyroid carcinomas. Cancer Res 57: 1798-806 [PMID:9135025]

14. Aust G, Hamann J, Schilling N and Wobus M. (2003) Detection of alternatively spliced EMR2 mRNAs in colorectal tumor cell lines but rare expression of the molecule in colorectal adenocarcinomas. Virchows Arch 443: 32-7 [PMID:12761622]

15. Aust G, Steinert M, Schütz A, Boltze C, Wahlbuhl M, Hamann J and Wobus M. (2002) CD97, but not its closely related EGF-TM7 family member EMR2, is expressed on gastric, pancreatic, and esophageal carcinomas. Am J Clin Pathol 118: 699-707 [PMID:12428789]

16. Aust G, Wandel E, Boltze C, Sittig D, Schütz A, Horn LC and Wobus M. (2006) Diversity of CD97 in smooth muscle cells. Cell Tissue Res 324: 139-47 [PMID:16408199]

17. Austyn JM and Gordon S. (1981) F4/80, a monoclonal antibody directed specifically against the mouse macrophage. Eur J Immunol 11: 805-15 [PMID:7308288]

18. Bahi-Buisson N, Poirier K, Boddaert N, Fallet-Bianco C, Specchio N, Bertini E, Caglayan O, Lascelles K, Elie C and Rambaud J et al.. (2010) GPR56-related bilateral frontoparietal polymicrogyria: further evidence for an overlap with the cobblestone complex. Brain 133: 3194209 [PMID:20929962]

19. Bai Y, Du L, Shen L, Zhang Y and Zhang L. (2009) GPR56 is highly expressed in neural stem cells but downregulated during differentiation. Neuroreport 20: 918-22 [PMID:19525879]

20. Baud V, Chissoe SL, Viegas-Péquignot E, Diriong S, N'Guyen VC, Roe BA and Lipinski M. (1995) 
EMR1, an unusual member in the family of hormone receptors with seven transmembrane segments. Genomics 26: 334-44 [PMID:7601460]

21. Bayin NS, Frenster JD, Kane JR, Rubenstein J, Modrek AS, Baitalmal R, Dolgalev I, Rudzenski K, Scarabottolo L and Crespi D et al.. (2016) GPR133 (ADGRD1), an adhesion G-protein-coupled receptor, is necessary for glioblastoma growth. Oncogenesis 5: e263 [PMID:27775701]

22. Beall SA, Boekelheide K and Johnson KJ. (2005) Hybrid GPCR/cadherin (Celsr) proteins in rat testis are expressed with cell type specificity and exhibit differential Sertoli cell-germ cell adhesion activity. J Androl 26: 529-38 [PMID:15955893]

23. Becker S, Wandel E, Wobus M, Schneider R, Amasheh S, Sittig D, Kerner C, Naumann R, Hamann J and Aust G. (2010) Overexpression of CD97 in intestinal epithelial cells of transgenic mice attenuates colitis by strengthening adherens junctions. PLoS ONE 5: e8507 [PMID:20084281]

24. Besnard T, Vaché C, Baux D, Larrieu L, Abadie C, Blanchet C, Odent S, Blanchet P, Calvas P and Hamel C et al.. (2012) Non-USH2A mutations in USH2 patients. Hum Mutat 33: 504-10 [PMID:22147658]

25. Beyer RP, Fry RC, Lasarev MR, McConnachie LA, Meira LB, Palmer VS, Powell CL, Ross PK, Bammler TK and Bradford BU et al.. (2007) Multicenter study of acetaminophen hepatotoxicity reveals the importance of biological endpoints in genomic analyses. Toxicol Sci 99: 326-37 [PMID:17562736]

26. Bhudia N, Desai S, King N, Ancellin N, Grillot D, Barnes AA and Dowell SJ. (2020) Author Correction: G Protein-Coupling of Adhesion GPCRs ADGRE2/EMR2 and ADGRE5/CD97, and Activation of G Protein Signalling by an Anti-EMR2 Antibody. Sci Rep 10: 5097 [PMID:32184438]

27. Bjarnadóttir TK, Fredriksson R, Höglund PJ, Gloriam DE, Lagerström MC and Schiöth HB. (2004) The human and mouse repertoire of the adhesion family of G-protein-coupled receptors. Genomics 84: 23-33 [PMID:15203201]

28. Bjarnadóttir TK, Geirardsdóttir K, Ingemansson M, Mirza MA, Fredriksson R and Schiöth HB. (2007) Identification of novel splice variants of Adhesion G protein-coupled receptors. Gene 387: 38-48 [PMID:17056209]

29. Bohnekamp J and Schöneberg T. (2011) Cell adhesion receptor GPR133 couples to Gs protein. $J$ Biol Chem 286: 41912-6 [PMID:22025619]

30. Bolliger MF, Martinelli DC and Südhof TC. (2011) The cell-adhesion G protein-coupled receptor BAI3 is a high-affinity receptor for C1q-like proteins. Proc Natl Acad Sci USA 108: 2534-9 [PMID:21262840]

31. Boltze C, Schneider-Stock R, Aust G, Mawrin C, Dralle H, Roessner A and Hoang-Vu C. (2002) CD97, CD95 and Fas-L clearly discriminate between chronic pancreatitis and pancreatic ductal adenocarcinoma in perioperative evaluation of cryocut sections. Pathol Int 52: 83-8 [PMID:11940212]

32. Bonaglia MC, Marelli S, Novara F, Commodaro S, Borgatti R, Minardo G, Memo L, Mangold E, Beri S and Zucca C et al.. (2010) Genotype-phenotype relationship in three cases with overlapping 19p13.12 microdeletions. Eur J Hum Genet 18: 1302-9 [PMID:20648052]

33. Bonnet C, Grati M, Marlin S, Levilliers J, Hardelin JP, Parodi M, Niasme-Grare M, Zelenika D, Délépine M and Feldmann D et al.. (2011) Complete exon sequencing of all known Usher syndrome genes greatly improves molecular diagnosis. Orphanet J Rare Dis 6: 21 [PMID:21569298]

34. Boucard AA, Ko J and Südhof TC. (2012) High affinity neurexin binding to cell adhesion Gprotein-coupled receptor CIRL1/latrophilin-1 produces an intercellular adhesion complex. J Biol Chem 287: 9399-413 [PMID:22262843]

35. Boyden SE, Desai A, Cruse G, Young ML, Bolan HC, Scott LM, Eisch AR, Long RD, Lee CC and Satorius CL et al.. (2016) Vibratory Urticaria Associated with a Missense Variant in ADGRE2. $N$ Engl J Med 374: 656-63 [PMID:26841242]

36. Bradley EC, Cunningham RL, Wilde C, Morgan RK, Klug EA, Letcher SM, Schöneberg T, Monk KR, Liebscher I and Petersen SC. (2019) In vivo identification of small molecules mediating Gpr126/Adgrg6 signaling during Schwann cell development. Ann N Y Acad Sci 1456: 44-63 [PMID:31529518]

37. Bridges JP, Ludwig MG, Mueller M, Kinzel B, Sato A, Xu Y, Whitsett JA and Ikegami M. (2013) Orphan G protein-coupled receptor GPR116 regulates pulmonary surfactant pool size. Am J Respir Cell Mol Biol 49: 348-57 [PMID:23590306]

38. Brown K, Filuta A, Ludwig MG, Seuwen K, Jaros J, Vidal S, Arora K, Naren AP, Kandasamy K and Parthasarathi K et al.. (2017) Epithelial Gpr116 regulates pulmonary alveolar homeostasis via Gq/11 signaling. JCI Insight 2 [PMID:28570277]

39. Buneman P, Christie G, Davies JA, Dimitrellou R, Harding SD, Pawson AJ, Sharman JL and Wu Y. (2020) Why data citation isn't working, and what to do about it Database 2020 [PMID:32367113]

40. Caddy J, Wilanowski T, Darido C, Dworkin S, Ting SB, Zhao Q, Rank G, Auden A, Srivastava S, 
Papenfuss TA, Murdoch JN, Humbert PO, Parekh V, Boulos N, Weber T, Zuo J, Cunningham JM and Jane SM. (2010) Epidermal wound repair is regulated by the planar cell polarity signaling pathway. Dev Cell 19: 138-47 [PMID:20643356]

41. Caminschi I, Lucas KM, O'Keeffe MA, Hochrein H, Laâbi Y, Köntgen F, Lew AM, Shortman K and Wright MD. (2001) Molecular cloning of F4/80-like-receptor, a seven-span membrane protein expressed differentially by dendritic cell and monocyte-macrophage subpopulations. $J$ Immunol 167: 3570-6 [PMID:11564768]

42. Caminschi I, Vandenabeele S, Sofi M, McKnight AJ, Ward N, Brodnicki TC, Toy T, Lahoud M, Maraskovsky E, Shortman K and Wright MD. (2006) Gene structure and transcript analysis of the human and mouse EGF-TM7 molecule, FIRE. DNA Seq 17: 8-14 [PMID:16753812]

43. Carr JC, Boese EA, Spanheimer PM, Dahdaleh FS, Martin M, Calva D, Schafer B, Thole DM, Braun T and O'Dorisio TM et al.. (2012) Differentiation of small bowel and pancreatic neuroendocrine tumors by gene-expression profiling. Surgery 152: 998-1007 [PMID:23158174]

44. Carroll N, Hughes L, McEntee G and Parle-McDermott A. (2012) Investigation of the molecular response to folate metabolism inhibition. J Nutr Biochem 23: 1531-6 [PMID:22402366]

45. Carson-Walter EB, Watkins DN, Nanda A, Vogelstein B, Kinzler KW and St Croix B. (2001) Cell surface tumor endothelial markers are conserved in mice and humans. Cancer Res 61: 6649-55 [PMID:11559528]

46. Carver EA, Hamann J, Olsen AS and Stubbs L. (1999) Physical mapping of EMR1 and CD97 in human Chromosome 19 and assignment of Cd97 to mouse Chromosome 8 suggest an ancient genomic duplication. Mamm Genome 10: 1039-40 [PMID:10501980]

47. Chan YF, Jones FC, McConnell E, Bryk J, Bünger L and Tautz D. (2012) Parallel selection mapping using artificially selected mice reveals body weight control loci. Curr Biol 22: 794-800 [PMID:22445301]

48. Chang GW, Davies JQ, Stacey M, Yona S, Bowdish DM, Hamann J, Chen TC, Lin CY, Gordon S and Lin HH. (2007) CD312, the human adhesion-GPCR EMR2, is differentially expressed during differentiation, maturation, and activation of myeloid cells. Biochem Biophys Res Commun 353: 133-8 [PMID:17174274]

49. Chang GW, Hsiao CC, Peng YM, Vieira Braga FA, Kragten NA, Remmerswaal EB, van de Garde MD, Straussberg R, König GM and Kostenis E et al.. (2016) The Adhesion G Protein-Coupled Receptor GPR56/ADGRG1 Is an Inhibitory Receptor on Human NK Cells. Cell Rep 15: 1757-70 [PMID:27184850]

50. Chang J, Mancuso MR, Maier C, Liang X, Yuki K, Yang L, Kwong JW, Wang J, Rao V and Vallon $\mathrm{M}$ et al.. (2017) Gpr124 is essential for blood-brain barrier integrity in central nervous system disease. Nat Med 23: 450-460 [PMID:28288111]

51. Chase A, Ernst T, Fiebig A, Collins A, Grand F, Erben P, Reiter A, Schreiber S and Cross NC. (2010) TFG, a target of chromosome translocations in lymphoma and soft tissue tumors, fuses to GPR128 in healthy individuals. Haematologica 95: 20-6 [PMID:19797732]

52. Chen G, Yang L, Begum S and Xu L. (2010) GPR56 is essential for testis development and male fertility in mice. Dev Dyn 239: 3358-67 [PMID:20981830]

53. Chen ML and Chen $\mathrm{CH}$. (2005) Microarray analysis of differentially expressed genes in rat frontal cortex under chronic risperidone treatment. Neuropsychopharmacology 30: 268-77 [PMID:15536490]

54. Chen TY, Hwang TL, Lin CY, Lin TN, Lai HY, Tsai WP and Lin HH. (2011) EMR2 receptor ligation modulates cytokine secretion profiles and cell survival of lipopolysaccharide-treated neutrophils. Chang Gung Med J 34: 468-77 [PMID:22035891]

55. Chiang NY, Chang GW, Huang YS, Peng YM, Hsiao CC, Kuo ML and Lin HH. (2016) Heparin interacts with the adhesion GPCR GPR56, reduces receptor shedding, and promotes cell adhesion and motility. J Cell Sci 129: 2156-69 [PMID:27068534]

56. Chiba Y, Yoshizaki K, Saito K, Ikeuchi T, Iwamoto T, Rhodes C, Nakamura T, de Vega S, Morell RJ and Boger ET et al.. (2020) G protein-coupled receptor Gpr115 (Adgrf4) is required for enamel mineralization mediated by ameloblasts. J Biol Chem 295: 15328-15341 [PMID:32868297]

57. Chidambaram A, Fillmore HL, Van Meter TE, Dumur CI and Broaddus WC. (2012) Novel report of expression and function of CD97 in malignant gliomas: correlation with Wilms tumor 1 expression and glioma cell invasiveness. J Neurosurg 116: 843-53 [PMID:22313360]

58. Cho C, Smallwood PM and Nathans J. (2017) Reck and Gpr124 Are Essential Receptor Cofactors for Wnt7a/Wnt7b-Specific Signaling in Mammalian CNS Angiogenesis and Blood-Brain Barrier Regulation. Neuron 95: 1056-1073.e5 [PMID:28803732]

59. Chong ZS, Ohnishi S, Yusa K and Wright GJ. (2018) Pooled extracellular receptor-ligand interaction screening using CRISPR activation. Genome Biol 19: 205 [PMID:30477585]

60. Corbett AJ, Caminschi I, McKenzie BS, Brady JL, Wright MD, Mottram PL, Hogarth PM, Hodder AN, Zhan Y and Tarlinton DM et al.. (2005) Antigen delivery via two molecules on the CD8dendritic cell subset induces humoral immunity in the absence of conventional "danger". Eur J Immunol 35: 2815-25 [PMID:16143986] 
61. Cork SM, Kaur B, Devi NS, Cooper L, Saltz JH, Sandberg EM, Kaluz S and Van Meir EG. (2012) A proprotein convertase/MMP-14 proteolytic cascade releases a novel $40 \mathrm{kDa}$ vasculostatin from tumor suppressor BAI1. Oncogene 31: 5144-52 [PMID:22330140]

62. Cortijo C, Gouzi M, Tissir F and Grapin-Botton A. (2012) Planar cell polarity controls pancreatic Beta cell differentiation and glucose homeostasis. Cell Rep 2: 1593-606 [PMID:23177622]

63. Cullen M, Elzarrad MK, Seaman S, Zudaire E, Stevens J, Yang MY, Li X, Chaudhary A, Xu L and Hilton MB et al.. (2011) GPR124, an orphan G protein-coupled receptor, is required for CNSspecific vascularization and establishment of the blood-brain barrier. Proc Natl Acad Sci USA 108: 5759-64 [PMID:21421844]

64. Curtin JA, Quint E, Tsipouri V, Arkell RM, Cattanach B, Copp AJ, Henderson DJ, Spurr N, Stanier $\mathrm{P}$ and Fisher EM et al.. (2003) Mutation of Celsr1 disrupts planar polarity of inner ear hair cells and causes severe neural tube defects in the mouse. Curr Biol 13: 1129-33 [PMID:12842012]

65. Das S, Owen KA, Ly KT, Park D, Black SG, Wilson JM, Sifri CD, Ravichandran KS, Ernst PB and Casanova JE. (2011) Brain angiogenesis inhibitor 1 (BAI1) is a pattern recognition receptor that mediates macrophage binding and engulfment of Gram-negative bacteria. Proc Natl Acad Sci USA 108: 2136-41 [PMID:21245295]

66. Davidson B, Stavnes HT, Risberg B, Nesland JM, Wohlschlaeger J, Yang Y, Shih IeM and Wang TL. (2012) Gene expression signatures differentiate adenocarcinoma of lung and breast origin in effusions. Hum Pathol 43: 684-94 [PMID:21937081]

67. Davies B, Baumann C, Kirchhoff C, Ivell R, Nubbemeyer R, Habenicht UF, Theuring F and Gottwald U. (2004) Targeted deletion of the epididymal receptor HE6 results in fluid dysregulation and male infertility. Mol Cell Biol 24: 8642-8 [PMID:15367682]

68. Davies B, Behnen M, Cappallo-Obermann H, Spiess AN, Theuring F and Kirchhoff C. (2007) Novel epididymis-specific mRNAs downregulated by HE6/Gpr64 receptor gene disruption. Mol Reprod Dev 74: 539-53 [PMID:17034053]

69. Davies JQ, Lin HH, Stacey M, Yona S, Chang GW, Gordon S, Hamann J, Campo L, Han C and Chan P et al.. (2011) Leukocyte adhesion-GPCR EMR2 is aberrantly expressed in human breast carcinomas and is associated with patient survival. Oncol Rep 25: 619-27 [PMID:21174063]

70. de Wilde J, Mohren R, van den Berg S, Boekschoten M, Dijk KW, de Groot P, Müller M, Mariman E and Smit E. (2008) Short-term high fat-feeding results in morphological and metabolic adaptations in the skeletal muscle of C57BL/6J mice. Physiol Genomics 32: 360-9 [PMID:18042831]

71. Deaciuc IV, Arteel GE, Peng X, Hill DB and McClain CJ. (2004) Gene expression in the liver of rats fed alcohol by means of intragastric infusion. Alcohol 33: 17-30 [PMID:15353170]

72. Demberg LM, Rothemund S, Schöneberg T and Liebscher I. (2015) Identification of the tethered peptide agonist of the adhesion G protein-coupled receptor GPR64/ADGRG2. Biochem Biophys Res Commun 464: 743-7 [PMID:26188515]

73. Demberg LM, Winkler J, Wilde C, Simon KU, Schön J, Rothemund S, Schöneberg T, Prömel S and Liebscher I. (2017) Activation of Adhesion G Protein-coupled Receptors: AGONIST SPECIFICITY OF STACHEL SEQUENCE-DERIVED PEPTIDES. J Biol Chem 292: 4383-4394 [PMID:28154189]

74. DeRosse P, Lencz T, Burdick KE, Siris SG, Kane JM and Malhotra AK. (2008) The genetics of symptom-based phenotypes: toward a molecular classification of schizophrenia. Schizophr Bull 34: 1047-53 [PMID:18628273]

75. Devenport D and Fuchs E. (2008) Planar polarization in embryonic epidermis orchestrates global asymmetric morphogenesis of hair follicles. Nat Cell Biol 10: 1257-68 [PMID:18849982]

76. Devenport D, Oristian D, Heller E and Fuchs E. (2011) Mitotic internalization of planar cell polarity proteins preserves tissue polarity. Nat Cell Biol 13: 893-902 [PMID:21743464]

77. Deák F, Liu X, Khvotchev M, Li G, Kavalali ET, Sugita S and Südhof TC. (2009) Alpha-latrotoxin stimulates a novel pathway of $\mathrm{Ca} 2+-$ dependent synaptic exocytosis independent of the classical synaptic fusion machinery. J Neurosci 29: 8639-48 [PMID:19587270]

78. Dieterich LC, Mellberg S, Langenkamp E, Zhang L, Zieba A, Salomäki H, Teichert M, Huang H, Edqvist PH and Kraus T et al.. (2012) Transcriptional profiling of human glioblastoma vessels indicates a key role of VEGF-A and TGFß2 in vascular abnormalization. J Pathol 228: 378-90 [PMID:22786655]

79. Diez-Roux G, Banfi S, Sultan M, Geffers L, Anand S, Rozado D, Magen A, Canidio E, Pagani M and Peluso I et al.. (2011) A high-resolution anatomical atlas of the transcriptome in the mouse embryo. PLoS Biol 9: e1000582 [PMID:21267068]

80. Dillman 3rd JF, Phillips CS, Dorsch LM, Croxton MD, Hege AI, Sylvester AJ, Moran TS and Sciuto AM. (2005) Genomic analysis of rodent pulmonary tissue following bis-(2-chloroethyl) sulfide exposure. Chem Res Toxicol 18: 28-34 [PMID:15651846]

81. Duda DG, Sunamura M, Lozonschi L, Yokoyama T, Yatsuoka T, Motoi F, Horii A, Tani K, Asano S and Nakamura Y et al.. (2002) Overexpression of the p53-inducible brain-specific angiogenesis inhibitor 1 suppresses efficiently tumour angiogenesis. Br J Cancer 86: 490-6 [PMID:11875720]

82. Duman JG, Mulherkar S, Tu YK, Erikson KC, Tzeng CP, Mavratsas VC, Ho TS and Tolias KF. 
(2019) The adhesion-GPCR BAI1 shapes dendritic arbors via Bcr-mediated RhoA activation causing late growth arrest. Elife 8 [PMID:31461398]

83. Ebermann I, Wiesen MH, Zrenner E, Lopez I, Pigeon R, Kohl S, Löwenheim H, Koenekoop RK and Bolz HJ. (2009) GPR98 mutations cause Usher syndrome type 2 in males. J Med Genet 46: 277-80 [PMID:19357117]

84. Eichler W, Aust G and Hamann D. (1994) Characterization of an early activation-dependent antigen on lymphocytes defined by the monoclonal antibody BL-Ac(F2). Scand J Immunol 39: 111-5 [PMID:8290889]

85. Eichler W, Hamann J and Aust G. (1997) Expression characteristics of the human CD97 antigen. Tissue Antigens 50: 429-38 [PMID:9389316]

86. Erkan M, Weis N, Pan Z, Schwager C, Samkharadze T, Jiang X, Wirkner U, Giese NA, Ansorge W, Debus J, Huber PE, Friess H, Abdollahi A and Kleeff J. (2010) Organ-, inflammation- and cancer specific transcriptional fingerprints of pancreatic and hepatic stellate cells. Mol Cancer 9: 88 [PMID:20416094]

87. Ernst T, Chase A, Zoi K, Waghorn K, Hidalgo-Curtis C, Score J, Jones A, Grand F, Reiter A and Hochhaus A et al.. (2010) Transcription factor mutations in myelodysplastic/myeloproliferative neoplasms. Haematologica 95: 1473-80 [PMID:20421268]

88. Eubelen M, Bostaille N, Cabochette P, Gauquier A, Tebabi P, Dumitru AC, Koehler M, Gut P, Alsteens D and Stainier DYR et al.. (2018) A molecular mechanism for Wnt ligand-specific signaling. Science $\mathbf{3 6 1}$ [PMID:30026314]

89. Feng J, Xu Y, Wang M, Ruan Y, So KF, Tissir F, Goffinet A and Zhou L. (2012) A role for atypical cadherin Celsr3 in hippocampal maturation and connectivity. J Neurosci 32: 13729-43 [PMID:23035085]

90. Fenstermaker AG, Prasad AA, Bechara A, Adolfs Y, Tissir F, Goffinet A, Zou Y and Pasterkamp RJ. (2010) Wnt/planar cell polarity signaling controls the anterior-posterior organization of monoaminergic axons in the brainstem. J Neurosci 30: 16053-64 [PMID:21106844]

91. Fitzmaurice CJ, Brown LE, Kronin V and Jackson DC. (2000) The geometry of synthetic peptidebased immunogens affects the efficiency of $\mathrm{T}$ cell stimulation by professional antigen-presenting cells. Int Immunol 12: 527-35 [PMID:10744654]

92. Flicek P, Ahmed I, Amode MR, Barrell D, Beal K, Brent S, Carvalho-Silva D, Clapham P, Coates $\mathrm{G}$ and Fairley S et al.. (2013) Ensembl 2013. Nucleic Acids Res 41: D48-55 [PMID:23203987]

93. Florian S, Sonneck K, Czerny M, Hennersdorf F, Hauswirth AW, Bühring HJ and Valent P. (2006) Detection of novel leukocyte differentiation antigens on basophils and mast cells by HLDA8 antibodies. Allergy 61: 1054-62 [PMID:16918507]

94. Foord SM, Jupe S and Holbrook J. (2002) Bioinformatics and type II G-protein-coupled receptors. Biochem Soc Trans 30: 473-9 [PMID:12196118]

95. Formstone CJ, Barclay J, Rees M and Little PF. (2000) Chromosomal localization of Celsr2 and Celsr3 in the mouse; Celsr3 is a candidate for the tippy (tip) lethal mutant on chromosome 9. Mamm Genome 11: 392-4 [PMID:10790539]

96. Formstone CJ and Little PF. (2001) The flamingo-related mouse Celsr family (Celsr1-3) genes exhibit distinct patterns of expression during embryonic development. Mech Dev 109: 91-94 [PMID:11677057]

97. Formstone CJ, Moxon C, Murdoch J, Little P and Mason I. (2010) Basal enrichment within neuroepithelia suggests novel function(s) for Celsr1 protein. Mol Cell Neurosci 44: 210-22 [PMID:20353824]

98. Fransen NL, Hsiao CC, van der Poel M, Engelenburg HJ, Verdaasdonk K, Vincenten MCJ, Remmerswaal EBM, Kuhlmann T, Mason MRJ and Hamann J et al.. (2020) Tissue-resident memory T cells invade the brain parenchyma in multiple sclerosis white matter lesions. Brain 143: 1714-1730 [PMID:32400866]

99. Fredriksson R, Gloriam DE, Höglund PJ, Lagerström MC and Schiöth HB. (2003) There exist at least 30 human G-protein-coupled receptors with long Ser/Thr-rich N-termini. Biochem Biophys Res Commun 301: 725-34 [PMID:12565841]

100. Fredriksson R, Lagerström MC, Höglund PJ and Schiöth HB. (2002) Novel human G proteincoupled receptors with long N-terminals containing GPS domains and Ser/Thr-rich regions. FEBS Lett 531: 407-14 [PMID:12435584]

101. Fredriksson R, Lagerström MC, Lundin LG and Schiöth HB. (2003) The G-protein-coupled receptors in the human genome form five main families. Phylogenetic analysis, paralogon groups, and fingerprints. Mol Pharmacol 63: 1256-72 [PMID:12761335]

102. Fukuzawa T, Ishida J, Kato A, Ichinose T, Ariestanti DM, Takahashi T, Ito K, Abe J, Suzuki T and Wakana S et al.. (2013) Lung surfactant levels are regulated by Ig-Hepta/GPR116 by monitoring surfactant protein D. PLoS ONE 8: e69451 [PMID:23922714]

103. Galle J, Sittig D, Hanisch I, Wobus M, Wandel E, Loeffler M and Aust G. (2006) Individual cellbased models of tumor-environment interactions: Multiple effects of CD97 on tumor invasion. Am J Pathol 169: 1802-11 [PMID:17071601]

104. Galligan CL, Baig E, Bykerk V, Keystone EC and Fish EN. (2007) Distinctive gene expression 
signatures in rheumatoid arthritis synovial tissue fibroblast cells: correlates with disease activity. Genes Immun 8: 480-91 [PMID:17568789]

105. Giera S, Deng Y, Luo R, Ackerman SD, Mogha A, Monk KR, Ying Y, Jeong SJ, Makinodan M and Bialas AR et al.. (2015) The adhesion G protein-coupled receptor GPR56 is a cell-autonomous regulator of oligodendrocyte development. Nat Commun 6: 6121 [PMID:25607655]

106. Glaeser RM, Zilker A, Radermacher M, Gaub HE, Hartmann T and Baumeister W. (1991) Interfacial energies and surface-tension forces involved in the preparation of thin, flat crystals of biological macromolecules for high-resolution electron microscopy. J Microsc 161: 21-45 [PMID:2016735]

107. Goodyear R and Richardson G. (1999) The ankle-link antigen: an epitope sensitive to calcium chelation associated with the hair-cell surface and the calycal processes of photoreceptors. $J$ Neurosci 19: 3761-72 [PMID:10234008]

108. Goodyear RJ and Richardson GP. (2003) A novel antigen sensitive to calcium chelation that is associated with the tip links and kinocilial links of sensory hair bundles. J Neurosci 23: 4878-87 [PMID:12832510]

109. Gordon S, Hamann J, Lin HH and Stacey M. (2011) F4/80 and the related adhesion-GPCRs. Eur J Immunol 41: 2472-6 [PMID:21952799]

110. Gordon S, Lawson L, Rabinowitz S, Crocker PR, Morris L and Perry VH. (1992) Antigen markers of macrophage differentiation in murine tissues. Curr Top Microbiol Immunol 181: 1-37 [PMID:1424778]

111. Gordon S, Perry VH, Rabinowitz S, Chung LP and Rosen H. (1988) Plasma membrane receptors of the mononuclear phagocyte system. J Cell Sci Suppl 9: 1-26 [PMID:3077135]

112. Gottwald U, Davies B, Fritsch M and Habenicht UF. (2006) New approaches for male fertility control: HE6 as an example of a putative target. Mol Cell Endocrinol 250: 49-57 [PMID:16442214]

113. Gouveia LO, Sobral J, Vicente AM, Ferro JM and Oliveira SA. (2011) Replication of the CELSR1 association with ischemic stroke in a Portuguese case-control cohort. Atherosclerosis 217: $260-2$ [PMID:21511255]

114. Gray JX, Haino M, Roth MJ, Maguire JE, Jensen PN, Yarme A, Stetler-Stevenson MA, Siebenlist U and Kelly K. (1996) CD97 is a processed, seven-transmembrane, heterodimeric receptor associated with inflammation. J Immunol 157: 5438-47 [PMID:8955192]

115. Gromova P, Ralea S, Lefort A, Libert F, Rubin BP, Erneux C and Vanderwinden JM. (2009) Kit K641E oncogene up-regulates Sprouty homolog 4 and trophoblast glycoprotein in interstitial cells of Cajal in a murine model of gastrointestinal stromal tumours. J Cell Mol Med 13: 1536-48 [PMID:19453770]

116. GTExPortal. Gene Page ADGRD2

117. Gupte J, Swaminath G, Danao J, Tian H, Li Y and Wu X. (2012) Signaling property study of adhesion G-protein-coupled receptors. FEBS Lett 586: 1214-9 [PMID:22575658]

118. Györffy B, Surowiak P, Kiesslich O, Denkert C, Schäfer R, Dietel M and Lage H. (2006) Gene expression profiling of 30 cancer cell lines predicts resistance towards 11 anticancer drugs at clinically achieved concentrations. Int J Cancer 118: 1699-712 [PMID:16217747]

119. Hadjantonakis AK, Formstone CJ and Little PF. (1998) mCelsr1 is an evolutionarily conserved seven-pass transmembrane receptor and is expressed during mouse embryonic development. Mech Dev 78: 91-5 [PMID:9858697]

120. Hadjantonakis AK, Sheward WJ, Harmar AJ, de Galan L, Hoovers JM and Little PF. (1997) Celsr1, a neural-specific gene encoding an unusual seven-pass transmembrane receptor, maps to mouse chromosome 15 and human chromosome 22qter. Genomics 45: 97-104 [PMID:9339365]

121. Haitina T, Olsson F, Stephansson O, Alsiö J, Roman E, Ebendal T, Schiöth HB and Fredriksson R. (2008) Expression profile of the entire family of Adhesion G protein-coupled receptors in mouse and rat. BMC Neurosci 9: 43 [PMID:18445277]

122. Hamann J, Aust G, Araç D, Engel FB, Formstone C, Fredriksson R, Hall RA, Harty BL, Kirchhoff C and Knapp B et al.. (2015) International Union of Basic and Clinical Pharmacology. XCIV. Adhesion G protein-coupled receptors. Pharmacol Rev 67: 338-67 [PMID:25713288]

123. Hamann J, Koning N, Pouwels W, Ulfman LH, van Eijk M, Stacey M, Lin HH, Gordon S and Kwakkenbos MJ. (2007) EMR1, the human homolog of F4/80, is an eosinophil-specific receptor. Eur J Immunol 37: 2797-802 [PMID:17823986]

124. Hamann J, Kwakkenbos MJ, de Jong EC, Heus H, Olsen AS and van Lier RA. (2003) Inactivation of the EGF-TM7 receptor EMR4 after the Pan-Homo divergence. Eur J Immunol 33: 1365-1371 [PMID:12731063]

125. Hamann J, Stortelers C, Kiss-Toth E, Vogel B, Eichler W and van Lier RA. (1998) Characterization of the CD55 (DAF)-binding site on the seven-span transmembrane receptor CD97. Eur J Immunol 28: 1701-7 [PMID:9603477]

126. Hamann J, van Zeventer C, Bijl A, Molenaar C, Tesselaar K and van Lier RA. (2000) Molecular cloning and characterization of mouse CD97. Int Immunol 12: 439-48 [PMID:10744645] 
127. Hamann J, Vogel B, van Schijndel GM and van Lier RA. (1996) The seven-span transmembrane receptor CD97 has a cellular ligand (CD55, DAF). J Exp Med 184: 1185-9 [PMID:9064337]

128. Hamann J, Wishaupt JO, van Lier RA, Smeets TJ, Breedveld FC and Tak PP. (1999) Expression of the activation antigen CD97 and its ligand CD55 in rheumatoid synovial tissue. Arthritis Rheum 42: 650-8 [PMID:10211878]

129. Hamoud N, Tran V, Croteau LP, Kania A and Côté JF. (2014) G-protein coupled receptor BAI3 promotes myoblast fusion in vertebrates. Proc Natl Acad Sci USA 111: 3745-50 [PMID:24567399]

130. Han SL, Xu C, Wu XL, Li JL, Liu Z and Zeng QQ. (2010) The impact of expressions of CD97 and its ligand CD55 at the invasion front on prognosis of rectal adenocarcinoma. Int J Colorectal Dis 25: 695-702 [PMID:20339853]

131. Hancock DB, Eijgelsheim M, Wilk JB, Gharib SA, Loehr LR, Marciante KD, Franceschini N, van Durme YM, Chen TH and Barr RG et al.. (2010) Meta-analyses of genome-wide association studies identify multiple loci associated with pulmonary function. Nat Genet 42: 45-52 [PMID:20010835]

132. Hardcastle J, Kurozumi K, Dmitrieva N, Sayers MP, Ahmad S, Waterman P, Weissleder R, Chiocca EA and Kaur B. (2010) Enhanced antitumor efficacy of vasculostatin (Vstat120) expressing oncolytic HSV-1. Mol Ther 18: 285-94 [PMID:19844198]

133. Harkensee C, Oka A, Onizuka M, Middleton PG, Inoko H, Nakaoka H, Gennery AR, Ando K, Morishima Y and Japan Marrow Donor Programme (JMDP). (2013) Microsatellite scanning of the immunogenome associates MAPK14 and ELTD1 with graft-versus-host disease in hematopoietic stem cell transplantation. Immunogenetics 65: 417-27 [PMID:23474535]

134. Harvey RC, Mullighan CG, Wang X, Dobbin KK, Davidson GS, Bedrick EJ, Chen IM, Atlas SR, Kang $\mathrm{H}$ and Ar K et al.. (2010) Identification of novel cluster groups in pediatric high-risk Bprecursor acute lymphoblastic leukemia with gene expression profiling: correlation with genome-wide DNA copy number alterations, clinical characteristics, and outcome. Blood 116: 4874-84 [PMID:20699438]

135. He L, Sun Y, Patrakka J, Mostad P, Norlin J, Xiao Z, Andrae J, Tryggvason K, Samuelsson T and Betsholtz C et al.. (2007) Glomerulus-specific mRNA transcripts and proteins identified through kidney expressed sequence tag database analysis. Kidney Int 71: 889-900 [PMID:17332733]

136. He Z, Kokkinaki M, Jiang J, Dobrinski I and Dym M. (2010) Isolation, characterization, and culture of human spermatogonia. Biol Reprod 82: 363-72 [PMID:19846602]

137. He Z, Kokkinaki M, Jiang J, Zeng W, Dobrinski I and Dym M. (2012) Isolation of human male germ-line stem cells using enzymatic digestion and magnetic-activated cell sorting. Methods Mol Biol 825: 45-57 [PMID:22144235]

138. Hermle T, Guida MC, Beck S, Helmstädter S and Simons M. (2013) Drosophila ATP6AP2/VhaPRR functions both as a novel planar cell polarity core protein and a regulator of endosomal trafficking. EMBO J 32: 245-59 [PMID:23292348]

139. Hilgert N, Kahrizi K, Dieltjens N, Bazazzadegan N, Najmabadi H, Smith RJ and Van Camp G. (2009) A large deletion in GPR98 causes type IIC Usher syndrome in male and female members of an Iranian family. J Med Genet 46: 272-6 [PMID:19357116]

140. Hoang-Vu C, Bull K, Schwarz I, Krause G, Schmutzler C, Aust G, Köhrle J and Dralle H. (1999) Regulation of CD97 protein in thyroid carcinoma. J Clin Endocrinol Metab 84: 1104-9 [PMID:10084602]

141. Hoek RM, de Launay D, Kop EN, Yilmaz-Elis AS, Lin F, Reedquist KA, Verbeek JS, Medof ME, Tak PP and Hamann J. (2010) Deletion of either CD55 or CD97 ameliorates arthritis in mouse models. Arthritis Rheum 62: 1036-42 [PMID:20131275]

142. Homma S, Shimada T, Hikake T and Yaginuma H. (2009) Expression pattern of LRR and Ig domain-containing protein (LRRIG protein) in the early mouse embryo. Gene Expr Patterns 9: 126 [PMID:18848646]

143. Hsiao CC, Chu TY, Wu CJ, van den Biggelaar M, Pabst C, Hébert J, Kuijpers TW, Scicluna BP, I KY and Chen TC et al.. (2018) The Adhesion G Protein-Coupled Receptor GPR97/ADGRG3 Is Expressed in Human Granulocytes and Triggers Antimicrobial Effector Functions. Front Immunol 9: 2830 [PMID:30559745]

144. Hsiao CC, van der Poel M, van Ham TJ and Hamann J. (2019) Macrophages Do Not Express the Phagocytic Receptor BAI1/ADGRB1. Front Immunol 10: 962 [PMID:31130954]

145. Huang Y, Fan J, Yang J and Zhu GZ. (2008) Characterization of GPR56 protein and its suppressed expression in human pancreatic cancer cells. Mol Cell Biochem 308: 133-9 [PMID:17932623]

146. Huang YS, Chiang NY, Hu CH, Hsiao CC, Cheng KF, Tsai WP, Yona S, Stacey M, Gordon S and Chang GW et al.. (2012) Activation of myeloid cell-specific adhesion class G protein-coupled receptor EMR2 via ligation-induced translocation and interaction of receptor subunits in lipid raft microdomains. Mol Cell Biol 32: 1408-20 [PMID:22310662]

147. Ichtchenko K, Bittner MA, Krasnoperov V, Little AR, Chepurny O, Holz RW and Petrenko AG. (1999) A novel ubiquitously expressed alpha-latrotoxin receptor is a member of the CIRL family 
of G-protein-coupled receptors. J Biol Chem 274: 5491-8 [PMID:10026162]

148. Ichtchenko K, Khvotchev M, Kiyatkin N, Simpson L, Sugita S and Südhof TC. (1998) alphalatrotoxin action probed with recombinant toxin: receptors recruit alpha-latrotoxin but do not transduce an exocytotic signal. EMBO J 17: 6188-99 [PMID:9799228]

149. Iguchi T, Sakata K, Yoshizaki K, Tago K, Mizuno N and Itoh H. (2008) Orphan G protein-coupled receptor GPR56 regulates neural progenitor cell migration via a G alpha 12/13 and Rho pathway. J Biol Chem 283: 14469-78 [PMID:18378689]

150. Irmscher S, Brix SR, Zipfel SLH, Halder LD, Mutlutürk S, Wulf S, Girdauskas E, Reichenspurner H, Stahl RAK and Jungnickel B et al.. (2019) Serum FHR1 binding to necrotic-type cells activates monocytic inflammasome and marks necrotic sites in vasculopathies. Nat Commun 10: 2961 [PMID:31273197]

151. Ishikawa K, Nagase T, Suyama M, Miyajima N, Tanaka A, Kotani H, Nomura N and Ohara O. (1998) Prediction of the coding sequences of unidentified human genes. X. The complete sequences of 100 new cDNA clones from brain which can code for large proteins in vitro. DNA Res 5: 169-76 [PMID:9734811]

152. Ito J, Ito M, Nambu H, Fujikawa T, Tanaka K, Iwaasa H and Tokita S. (2009) Anatomical and histological profiling of orphan G-protein-coupled receptor expression in gastrointestinal tract of C57BL/6J mice. Cell Tissue Res 338: 257-69 [PMID:19763624]

153. Izadyar F, Wong J, Maki C, Pacchiarotti J, Ramos T, Howerton K, Yuen C, Greilach S, Zhao HH and Chow $\mathrm{M}$ et al.. (2011) Identification and characterization of repopulating spermatogonial stem cells from the adult human testis. Hum Reprod 26: 1296-306 [PMID:21349855]

154. Jackson VA, Mehmood S, Chavent M, Roversi P, Carrasquero M, Del Toro D, Seyit-Bremer G, Ranaivoson FM, Comoletti D and Sansom MS et al.. (2016) Super-complexes of adhesion GPCRs and neural guidance receptors. Nat Commun 7: 11184 [PMID:27091502]

155. Jackson VA, Meijer DH, Carrasquero M, van Bezouwen LS, Lowe ED, Kleanthous C, Janssen BJC and Seiradake E. (2018) Structures of Teneurin adhesion receptors reveal an ancient fold for cell-cell interaction. Nat Commun 9: 1079 [PMID:29540701]

156. Jacobson SG, Cideciyan AV, Aleman TS, Sumaroka A, Roman AJ, Gardner LM, Prosser HM, Mishra M, Bech-Hansen NT, Herrera W, Schwartz SB, Liu XZ, Kimberling WJ, Steel KP and Williams DS. (2008) Usher syndromes due to MYO7A, PCDH15, USH2A or GPR98 mutations share retinal disease mechanism. Hum Mol Genet 17: 2405-15 [PMID:18463160]

157. Jaspars LH, Vos W, Aust G, Van Lier RA and Hamann J. (2001) Tissue distribution of the human CD97 EGF-TM7 receptor. Tissue Antigens 57: 325-31 [PMID:11380941]

158. Jeong BC, Kim MY, Lee JH, Kee HJ, Kho DH, Han KE, Qian YR, Kim JK and Kim KK. (2006) Brainspecific angiogenesis inhibitor 2 regulates VEGF through GABP that acts as a transcriptional repressor. FEBS Lett 580: 669-76 [PMID:16412436]

159. Jeong SJ, Luo R, Li S, Strokes N and Piao X. (2012) Characterization of G protein-coupled receptor 56 protein expression in the mouse developing neocortex. J Comp Neurol 520: 2930-40 [PMID:22351047]

160. Kamesh N, Aradhyam GK and Manoj N. (2008) The repertoire of G protein-coupled receptors in the sea squirt Ciona intestinalis. BMC Evol Biol 8: 129 [PMID:18452600]

161. Kan Z, Jaiswal BS, Stinson J, Janakiraman V, Bhatt D, Stern HM, Yue P, Haverty PM, Bourgon R, Zheng J, Moorhead M, Chaudhuri S, Tomsho LP, Peters BA, Pujara K, Cordes S, Davis DP, Carlton VE, Yuan W, Li L, Wang W, Eigenbrot C, Kaminker JS, Eberhard DA, Waring P, Schuster SC, Modrusan Z, Zhang Z, Stokoe D, de Sauvage FJ, Faham M and Seshagiri S. (2010) Diverse somatic mutation patterns and pathway alterations in human cancers. Nature 466: 869-73 [PMID:20668451]

162. Kane AJ, Sughrue ME, Rutkowski MJ, Phillips JJ and Parsa AT. (2010) EMR-3: a potential mediator of invasive phenotypic variation in glioblastoma and novel therapeutic target. Neuroreport 21: 1018-22 [PMID:20827226]

163. Kang X, Xiao X, Harata M, Bai Y, Nakazaki Y, Soda Y, Kurita R, Tanaka T, Komine F, Izawa K, Kunisaki R, Setoyama M, Nishimori H, Natsume A, Sunamura M, Lozonshi L, Saitoh I, Tokino T, Asano S, Nakamura Y and Tani K. (2006) Antiangiogenic activity of BAI1 in vivo: implications for gene therapy of human glioblastomas. Cancer Gene Ther 13: 385-92 [PMID:16244591]

164. Kaur B, Cork SM, Sandberg EM, Devi NS, Zhang Z, Klenotic PA, Febbraio M, Shim H, Mao H, Tucker-Burden C, Silverstein RL, Brat DJ, Olson JJ and Van Meir EG. (2009) Vasculostatin inhibits intracranial glioma growth and negatively regulates in vivo angiogenesis through a CD36-dependent mechanism. Cancer Res 69: 1212-20 [PMID:19176395]

165. Ke N, Sundaram R, Liu G, Chionis J, Fan W, Rogers C, Awad T, Grifman M, Yu D and Wong-Staal F et al.. (2007) Orphan G protein-coupled receptor GPR56 plays a role in cell transformation and tumorigenesis involving the cell adhesion pathway. Mol Cancer Ther 6: 1840-50 [PMID:17575113]

166. Kee HJ, Ahn KY, Choi KC, Won Song J, Heo T, Jung S, Kim JK, Bae CS and Kim KK. (2004) Expression of brain-specific angiogenesis inhibitor 3 (BAI3) in normal brain and implications for BAI3 in ischemia-induced brain angiogenesis and malignant glioma. FEBS Lett 569: 307-16 
[PMID:15225653]

167. Kee HJ, Koh JT, Kim MY, Ahn KY, Kim JK, Bae CS, Park SS and Kim KK. (2002) Expression of brain-specific angiogenesis inhibitor 2 (BAI2) in normal and ischemic brain: involvement of BAI2 in the ischemia-induced brain angiogenesis. J Cereb Blood Flow Metab 22: 1054-67 [PMID:12218411]

168. Kim JJ, Park YM, Baik KH, Choi HY, Yang GS, Koh I, Hwang JA, Lee J, Lee YS and Rhee $\mathrm{H}$ et al.. (2012) Exome sequencing and subsequent association studies identify five amino acid-altering variants influencing human height. Hum Genet 131: 471-8 [PMID:21959382]

169. Kim YK, Moon S, Hwang MY, Kim DJ, Oh JH, Kim YJ, Han BG, Lee JY and Kim BJ. (2013) Genebased copy number variation study reveals a microdeletion at 12q24 that influences height in the Korean population. Genomics 101: 134-8 [PMID:23147675]

170. Kirchhoff C, Osterhoff C and Samalecos A. (2008) HE6/GPR64 adhesion receptor co-localizes with apical and subapical F-actin scaffold in male excurrent duct epithelia. Reproduction 136: 235-45 [PMID:18469038]

171. Knierim AB, Röthe J, Çakir MV, Lede V, Wilde C, Liebscher I, Thor D and Schöneberg T. (2019) Genetic basis of functional variability in adhesion G protein-coupled receptors. Sci Rep 9: 11036 [PMID:31363148]

172. Kobayashi A, Donaldson DS, Kanaya T, Fukuda S, Baillie JK, Freeman TC, Ohno H, Williams IR and Mabbott NA. (2012) Identification of novel genes selectively expressed in the follicleassociated epithelium from the meta-analysis of transcriptomics data from multiple mouse cell and tissue populations. DNA Res 19: 407-22 [PMID:22991451]

173. Koh JT, Kook H, Kee HJ, Seo YW, Jeong BC, Lee JH, Kim MY, Yoon KC, Jung S and Kim KK. (2004) Extracellular fragment of brain-specific angiogenesis inhibitor 1 suppresses endothelial cell proliferation by blocking alphavbeta5 integrin. Exp Cell Res 294: 172-84 [PMID:14980512]

174. Koh JT, Lee ZH, Ahn KY, Kim JK, Bae CS, Kim HH, Kee HJ and Kim KK. (2001) Characterization of mouse brain-specific angiogenesis inhibitor 1 (BAI1) and phytanoyl-CoA alpha-hydroxylaseassociated protein 1, a novel BAI1-binding protein. Brain Res Mol Brain Res 87: 223-37 [PMID:11245925]

175. Koirala S and Corfas G. (2010) Identification of novel glial genes by single-cell transcriptional profiling of Bergmann glial cells from mouse cerebellum. PLoS ONE 5: e9198 [PMID:20169146]

176. Koirala S, Jin Z, Piao X and Corfas G. (2009) GPR56-regulated granule cell adhesion is essential for rostral cerebellar development. J Neurosci 29: 7439-49 [PMID:19515912]

177. Kop EN, Kwakkenbos MJ, Teske GJ, Kraan MC, Smeets TJ, Stacey M, Lin HH, Tak PP and Hamann J. (2005) Identification of the epidermal growth factor-TM7 receptor EMR2 and its ligand dermatan sulfate in rheumatoid synovial tissue. Arthritis Rheum 52: 442-50 [PMID:15693006]

178. Kop EN, Matmati M, Pouwels W, Leclercq G, Tak PP and Hamann J. (2009) Differential expression of CD97 on human lymphocyte subsets and limited effect of CD97 antibodies on allogeneic T-cell stimulation. Immunol Lett 123: 160-8 [PMID:19428565]

179. Kou I, Takahashi Y, Johnson TA, Takahashi A, Guo L, Dai J, Qiu X, Sharma S, Takimoto A and Ogura Y et al.. (2013) Genetic variants in GPR126 are associated with adolescent idiopathic scoliosis. Nat Genet 45: 676-679 [PMID:23666238]

180. Kraja AT, Borecki IB, Tsai MY, Ordovas JM, Hopkins PN, Lai CQ, Frazier-Wood AC, Straka RJ, Hixson JE and Province MA et al.. (2013) Genetic analysis of 16 NMR-lipoprotein fractions in humans, the GOLDN study. Lipids 48: 155-65 [PMID:23192668]

181. Krasnoperov V, Lu Y, Buryanovsky L, Neubert TA, Ichtchenko K and Petrenko AG. (2002) Posttranslational proteolytic processing of the calcium-independent receptor of alpha-latrotoxin (CIRL), a natural chimera of the cell adhesion protein and the G protein-coupled receptor. Role of the G protein-coupled receptor proteolysis site (GPS) motif. J Biol Chem 277: 46518-26 [PMID:12270923]

182. Krasnoperov VG, Bittner MA, Beavis R, Kuang Y, Salnikow KV, Chepurny OG, Little AR, Plotnikov AN, Wu D and Holz RW et al.. (1997) alpha-Latrotoxin stimulates exocytosis by the interaction with a neuronal G-protein-coupled receptor. Neuron 18: 925-37 [PMID:9208860]

183. Kreienkamp HJ, Zitzer H, Gundelfinger ED, Richter D and Bockers TM. (2000) The calciumindependent receptor for alpha-latrotoxin from human and rodent brains interacts with members of the ProSAP/SSTRIP/Shank family of multidomain proteins. J Biol Chem 275: 32387 90 [PMID:10964907]

184. Kudo S, Konda R, Obara W, Kudo D, Tani K, Nakamura Y and Fujioka T. (2007) Inhibition of tumor growth through suppression of angiogenesis by brain-specific angiogenesis inhibitor 1 gene transfer in murine renal cell carcinoma. Oncol Rep 18: 785-91 [PMID:17786337]

185. Kuhnert F, Mancuso MR, Shamloo A, Wang HT, Choksi V, Florek M, Su H, Fruttiger M, Young WL and Heilshorn SC et al.. (2010) Essential regulation of CNS angiogenesis by the orphan G protein-coupled receptor GPR124. Science 330: 985-9 [PMID:21071672]

186. Kwakkenbos MJ, Chang GW, Lin HH, Pouwels W, de Jong EC, van Lier RA, Gordon S and Hamann J. (2002) The human EGF-TM7 family member EMR2 is a heterodimeric receptor 
expressed on myeloid cells. J Leukoc Biol 71: 854-62 [PMID:11994511]

187. Kwakkenbos MJ, Kop EN, Stacey M, Matmati M, Gordon S, Lin HH and Hamann J. (2004) The EGF-TM7 family: a postgenomic view. Immunogenetics 55: 655-66 [PMID:14647991]

188. Kwakkenbos MJ, Matmati M, Madsen O, Pouwels W, Wang Y, Bontrop RE, Heidt PJ, Hoek RM and Hamann J. (2006) An unusual mode of concerted evolution of the EGF-TM7 receptor chimera EMR2. FASEB J 20: 2582-4 [PMID:17068111]

189. Kwakkenbos MJ, Pouwels W, Matmati M, Stacey M, Lin HH, Gordon S, van Lier RA and Hamann J. (2005) Expression of the largest CD97 and EMR2 isoforms on leukocytes facilitates a specific interaction with chondroitin sulfate on B cells. J Leukoc Biol 77: 112-9 [PMID:15498814]

190. Labbe A, Liu A, Atherton J, Gizenko N, Fortier ME, Sengupta SM and Ridha J. (2012) Refining psychiatric phenotypes for response to treatment: contribution of LPHN3 in ADHD. Am J Med Genet B Neuropsychiatr Genet 159B: 776-85 [PMID:22851411]

191. Lagerström MC, Rabe N, Haitina T, Kalnina I, Hellström AR, Klovins J, Kullander K and Schiöth HB. (2007) The evolutionary history and tissue mapping of GPR123: specific CNS expression pattern predominantly in thalamic nuclei and regions containing large pyramidal cells. $J$ Neurochem 100: 1129-42 [PMID:17212699]

192. Lajus S, Vacher P, Huber D, Dubois M, Benassy MN, Ushkaryov Y and Lang J. (2006) Alphalatrotoxin induces exocytosis by inhibition of voltage-dependent $\mathrm{K}+$ channels and by stimulation of L-type Ca2 + channels via latrophilin in beta-cells. J Biol Chem 281: 5522-31 [PMID:16301314]

193. Le Quesne Stabej P, Saihan Z, Rangesh N, Steele-Stallard HB, Ambrose J, Coffey A, Emmerson J, Haralambous E, Hughes Y and Steel KP et al.. (2012) Comprehensive sequence analysis of nine Usher syndrome genes in the UK National Collaborative Usher Study. J Med Genet 49: 27-36 [PMID:22135276]

194. Lee J, Hever A, Willhite D, Zlotnik A and Hevezi P. (2005) Effects of RNA degradation on gene expression analysis of human postmortem tissues. FASEB J 19: 1356-8 [PMID:15955843]

195. Lee JW, Huang BX, Kwon H, Rashid MA, Kharebava G, Desai A, Patnaik S, Marugan J and Kim HY. (2016) Orphan GPR110 (ADGRF1) targeted by N-docosahexaenoylethanolamine in development of neurons and cognitive function. Nat Commun 7: 13123 [PMID:27759003]

196. Lee KT, Byun MJ, Kang KS, Park EW, Lee SH, Cho S, Kim H, Kim KW, Lee T and Park JE et al.. (2011) Neuronal genes for subcutaneous fat thickness in human and pig are identified by local genomic sequencing and combined SNP association study. PLoS ONE 6: e16356 [PMID:21311593]

197. Legrand F, Tomasevic N, Simakova O, Lee CC, Wang Z, Raffeld M, Makiya MA, Palath V, Leung J and Baer M et al.. (2014) The eosinophil surface receptor epidermal growth factor-like module containing mucin-like hormone receptor 1 (EMR1): a novel therapeutic target for eosinophilic disorders. J Allergy Clin Immunol 133: 1439-47, 1447.e1-8 [PMID:24530099]

198. Lei Y, Zhu H, Yang W, Ross ME, Shaw GM and Finnell RH. (2014) Identification of novel CELSR1 mutations in spina bifida. PLoS ONE 9: e92207 [PMID:24632739]

199. Leja J, Essaghir A, Essand M, Wester K, Oberg K, Tötterman TH, Lloyd R, Vasmatzis G, Demoulin JB and Giandomenico V. (2009) Novel markers for enterochromaffin cells and gastrointestinal neuroendocrine carcinomas. Mod Pathol 22: 261-72 [PMID:18953328]

200. Lelianova VG, Davletov BA, Sterling A, Rahman MA, Grishin EV, Totty NF and Ushkaryov YA. (1997) Alpha-latrotoxin receptor, latrophilin, is a novel member of the secretin family of $\mathrm{G}$ protein-coupled receptors. J Biol Chem 272: 21504-8 [PMID:9261169]

201. Lelyanova VG, Thomson D, Ribchester RR, Tonevitsky EA and Ushkaryov YA. (2009) Activation of alpha-latrotoxin receptors in neuromuscular synapses leads to a prolonged splash acetylcholine release. Bull Exp Biol Med 147: 701-3 [PMID:19902061]

202. Lennon G, Auffray C, Polymeropoulos M and Soares MB. (1996) The I.M.A.G.E. Consortium: an integrated molecular analysis of genomes and their expression. Genomics 33: 151-2 [PMID:8617505]

203. Lettre G, Jackson AU, Gieger C, Schumacher FR, Berndt SI, Sanna S, Eyheramendy S, Voight $\mathrm{BF}$, Butler JL and Guiducci C et al.. (2008) Identification of ten loci associated with height highlights new biological pathways in human growth. Nat Genet 40: 584-91 [PMID:18391950]

204. Li S, Jin Z, Koirala S, Bu L, Xu L, Hynes RO, Walsh CA, Corfas G and Piao X. (2008) GPR56 regulates pial basement membrane integrity and cortical lamination. J Neurosci 28: 5817-26 [PMID:18509043]

205. Li X, Roszko I, Sepich DS, Ni M, Hamm HE, Marlow FL and Solnica-Krezel L. (2013) Gpr125 modulates Dishevelled distribution and planar cell polarity signaling. Development 140: 302839 [PMID:23821037]

206. Liebscher I, Schön J, Petersen SC, Fischer L, Auerbach N, Demberg LM, Mogha A, Cöster M, Simon KU and Rothemund S et al.. (2014) A tethered agonist within the ectodomain activates the adhesion G protein-coupled receptors GPR126 and GPR133. Cell Rep 9: 2018-26 [PMID:25533341]

207. Liebscher I, Schöneberg T and Prömel S. (2013) Progress in demystification of adhesion G 
protein-coupled receptors. Biol Chem 394: 937-50 [PMID:23518449]

208. Lin HH, Chang GW, Davies JQ, Stacey M, Harris J and Gordon S. (2004) Autocatalytic cleavage of the EMR2 receptor occurs at a conserved G protein-coupled receptor proteolytic site motif. $J$ Biol Chem 279: 31823-32 [PMID:15150276]

209. Lin HH, Faunce DE, Stacey M, Terajewicz A, Nakamura T, Zhang-Hoover J, Kerley M, Mucenski ML, Gordon S and Stein-Streilein J. (2005) The macrophage F4/80 receptor is required for the induction of antigen-specific efferent regulatory T cells in peripheral tolerance. J Exp Med 201: 1615-25 [PMID:15883173]

210. Lin HH, Stacey M, Hamann J, Gordon S and McKnight AJ. (2000) Human EMR2, a novel EGFTM7 molecule on chromosome 19p13.1, is closely related to CD97. Genomics 67: 188-200 [PMID:10903844]

211. Lin HH, Stacey M, Saxby C, Knott V, Chaudhry Y, Evans D, Gordon S, McKnight AJ, Handford P and Lea S. (2001) Molecular analysis of the epidermal growth factor-like short consensus repeat domain-mediated protein-protein interactions: dissection of the CD97-CD55 complex. J Biol Chem 276: 24160-9 [PMID:11297558]

212. Lin HH, Stacey M, Stein-Streilein J and Gordon S. (2010) F4/80: the macrophage-specific adhesion-GPCR and its role in immunoregulation. Adv Exp Med Biol 706: 149-56 [PMID:21618834]

213. Lindenmaier LB, Parmentier N, Guo C, Tissir F and Wright KM. (2019) Dystroglycan is a scaffold for extracellular axon guidance decisions. Elife 8 [PMID:30758284]

214. Liu M, Parker RM, Darby K, Eyre HJ, Copeland NG, Crawford J, Gilbert DJ, Sutherland GR, Jenkins NA and Herzog H. (1999) GPR56, a novel secretin-like human G-protein-coupled receptor gene. Genomics 55: 296-305 [PMID:10049584]

215. Liu Z, Easson GWD, Zhao J, Makki N, Ahituv N, Hilton MJ, Tang SY and Gray RS. (2019) Dysregulation of STAT3 signaling is associated with endplate-oriented herniations of the intervertebral disc in Adgrg6 mutant mice. PLoS Genet 15: e1008096 [PMID:31652254]

216. Loberg RD, Wojno KJ, Day LL and Pienta KJ. (2005) Analysis of membrane-bound complement regulatory proteins in prostate cancer. Urology 66: 1321-6 [PMID:16360477]

217. LopezJimenez ND, Sainz E, Cavenagh MM, Cruz-Ithier MA, Blackwood CA, Battey JF and Sullivan SL. (2005) Two novel genes, Gpr113, which encodes a family 2 G-protein-coupled receptor, and Trcg1, are selectively expressed in taste receptor cells. Genomics 85: 472-82 [PMID:15780750]

218. Lum AM, Wang BB, Beck-Engeser GB, Li L, Channa N and Wabl M. (2010) Orphan receptor GPR110, an oncogene overexpressed in lung and prostate cancer. BMC Cancer 10: 40 [PMID:20149256]

219. Luo R, Jeong SJ, Jin Z, Strokes N, Li S and Piao X. (2011) G protein-coupled receptor 56 and collagen III, a receptor-ligand pair, regulates cortical development and lamination. Proc Natl Acad Sci USA 108: 12925-30 [PMID:21768377]

220. Luo R, Yang HM, Jin Z, Halley DJ, Chang BS, MacPherson L, Brueton L and Piao X. (2011) A novel GPR56 mutation causes bilateral frontoparietal polymicrogyria. Pediatr Neurol 45: 49-53 [PMID:21723461]

221. Maerker T, van Wijk E, Overlack N, Kersten FF, McGee J, Goldmann T, Sehn E, Roepman R, Walsh EJ and Kremer H et al.. (2008) A novel Usher protein network at the periciliary reloading point between molecular transport machineries in vertebrate photoreceptor cells. Hum Mol Genet 17: 71-86 [PMID:17906286]

222. Mah MW, Priel IE, Humen DP, Brown NE and Sproule BJ. (1989) Idiopathic pulmonary hemosiderosis, complete heart block and celiac disease. Can J Cardiol 5: 191-4 [PMID:2731063]

223. Malm E, Ponjavic V, Möller C, Kimberling WJ and Andréasson S. (2011) Phenotypes in defined genotypes including siblings with Usher syndrome. Ophthalmic Genet 32: 65-74 [PMID:21174530]

224. Marroni F, Pfeufer A, Aulchenko YS, Franklin CS, Isaacs A, Pichler I, Wild SH, Oostra BA, Wright AF, Campbell H, Witteman JC, Kääb S, Hicks AA, Gyllensten U, Rudan I, Meitinger T, Pattaro C, van Duijn CM, Wilson JF, Pramstaller PP and EUROSPAN Consortium. (2009) A genome-wide association scan of RR and QT interval duration in 3 European genetically isolated populations: the EUROSPAN project. Circ Cardiovasc Genet 2: 322-8 [PMID:20031603]

225. Martin GH, Roy N, Chakraborty S, Desrichard A, Chung SS, Woolthuis CM, Hu W, Berezniuk I, Garrett-Bakelman FE and Hamann J et al.. (2019) CD97 is a critical regulator of acute myeloid leukemia stem cell function. J Exp Med 216: 2362-2377 [PMID:31371381]

226. Martinez AF, Muenke M and Arcos-Burgos M. (2011) From the black widow spider to human behavior: Latrophilins, a relatively unknown class of $\mathrm{G}$ protein-coupled receptors, are implicated in psychiatric disorders. Am J Med Genet B Neuropsychiatr Genet 156B: 1-10 [PMID:21184579]

227. Martinez-Pomares L, Platt N, McKnight AJ, da Silva RP and Gordon S. (1996) Macrophage membrane molecules: markers of tissue differentiation and heterogeneity. Immunobiology 195 : 407-16 [PMID:8933147]

228. Martínez-Poveda B, García-Vilas JA, Cárdenas C, Melgarejo E, Quesada AR and Medina MA. 
(2013) The brominated compound aeroplysinin-1 inhibits proliferation and the expression of key pro- inflammatory molecules in human endothelial and monocyte cells. PLOS ONE 8: e55203 [PMID:23383109]

229. Mathiasen S, Palmisano T, Perry NA, Stoveken HM, Vizurraga A, McEwen DP, Okashah N, Langenhan T, Inoue A and Lambert NA et al.. (2020) G12/13 is activated by acute tethered agonist exposure in the adhesion GPCR ADGRL3. Nat Chem Biol 16: 1343-1350 [PMID:32778842]

230. Matmati M, Pouwels W, van Bruggen R, Jansen M, Hoek RM, Verhoeven AJ and Hamann J. (2007) The human EGF-TM7 receptor EMR3 is a marker for mature granulocytes. J Leukoc Biol 81: 440-8 [PMID:17108056]

231. Matsushita H, Lelianova VG and Ushkaryov YA. (1999) The latrophilin family: multiply spliced G protein-coupled receptors with differential tissue distribution. FEBS Lett 443: 348-52 [PMID:10025961]

232. McGarry MP and Stewart CC. (1991) Murine eosinophil granulocytes bind the murine macrophage-monocyte specific monoclonal antibody F4/80. J Leukoc Biol 50: 471-8 [PMID:1721083]

233. McGee J, Goodyear RJ, McMillan DR, Stauffer EA, Holt JR, Locke KG, Birch DG, Legan PK, White PC and Walsh EJ et al.. (2006) The very large G-protein-coupled receptor VLGR1: a component of the ankle link complex required for the normal development of auditory hair bundles. J Neurosci 26: 6543-53 [PMID:16775142]

234. McKnight AJ and Gordon S. (1998) The EGF-TM7 family: unusual structures at the leukocyte surface. J Leukoc Biol 63: 271-80 [PMID:9500513]

235. McKnight AJ, Macfarlane AJ, Dri P, Turley L, Willis AC and Gordon S. (1996) Molecular cloning of F4/80, a murine macrophage-restricted cell surface glycoprotein with homology to the Gprotein-linked transmembrane 7 hormone receptor family. J Biol Chem 271: 486-9 [PMID:8550607]

236. McKnight AJ, Macfarlane AJ, Seldin MF and Gordon S. (1997) Chromosome mapping of the Emr1 gene. Mamm Genome 8: 946 [PMID:9383301]

237. McMillan DR, Kayes-Wandover KM, Richardson JA and White PC. (2002) Very large G proteincoupled receptor-1, the largest known cell surface protein, is highly expressed in the developing central nervous system. J Biol Chem 277: 785-92 [PMID:11606593]

238. McMillan DR and White PC. (2004) Loss of the transmembrane and cytoplasmic domains of the very large G-protein-coupled receptor-1 (VLGR1 or Mass1) causes audiogenic seizures in mice. Mol Cell Neurosci 26: 322-9 [PMID:15207856]

239. McMillan DR and White PC. (2010) Studies on the very large G protein-coupled receptor: from initial discovery to determining its role in sensorineural deafness in higher animals. Adv Exp Med Biol 706: 76-86 [PMID:21618827]

240. Michalski N, Michel V, Bahloul A, Lefèvre G, Barral J, Yagi H, Chardenoux S, Weil D, Martin P and Hardelin JP et al.. (2007) Molecular characterization of the ankle-link complex in cochlear hair cells and its role in the hair bundle functioning. J Neurosci 27: 6478-88 [PMID:17567809]

241. Miller SJ, Jessen WJ, Mehta T, Hardiman A, Sites E, Kaiser S, Jegga AG, Li H, Upadhyaya M and Giovannini $\mathrm{M}$ et al.. (2009) Integrative genomic analyses of neurofibromatosis tumours identify SOX9 as a biomarker and survival gene. EMBO Mol Med 1: 236-48 [PMID:20049725]

242. Mogha A, Benesh AE, Patra C, Engel FB, Schöneberg T, Liebscher I and Monk KR. (2013) Gpr126 functions in Schwann cells to control differentiation and myelination via G-protein activation. J Neurosci 33: 17976-85 [PMID:24227709]

243. Monk KR, Naylor SG, Glenn TD, Mercurio S, Perlin JR, Dominguez C, Moens CB and Talbot WS. (2009) A G protein-coupled receptor is essential for Schwann cells to initiate myelination. Science 325: 1402-5 [PMID:19745155]

244. Monk KR, Oshima K, Jörs S, Heller S and Talbot WS. (2011) Gpr126 is essential for peripheral nerve development and myelination in mammals. Development 138: 2673-80 [PMID:21613327]

245. Mori K, Kanemura Y, Fujikawa H, Nakano A, Ikemoto H, Ozaki I, Matsumoto T, Tamura K, Yokota M and Arita N. (2002) Brain-specific angiogenesis inhibitor 1 (BAI1) is expressed in human cerebral neuronal cells. Neurosci Res 43: 69-74 [PMID:12074842]

246. Moriguchi T, Haraguchi K, Ueda N, Okada M, Furuya T and Akiyama T. (2004) DREG, a developmentally regulated $\mathrm{G}$ protein-coupled receptor containing two conserved proteolytic cleavage sites. Genes Cells 9: 549-60 [PMID:15189448]

247. Mustafa T, Klonisch T, Hombach-Klonisch S, Kehlen A, Schmutzler C, Koehrle J, Gimm O, Dralle $\mathrm{H}$ and Hoang-Vu C. (2004) Expression of CD97 and CD55 in human medullary thyroid carcinomas. Int J Oncol 24: 285-94 [PMID:14719104]

248. Müller A, Winkler J, Fiedler F, Sastradihardja T, Binder C, Schnabel R, Kungel J, Rothemund S, Hennig C and Schöneberg T et al.. (2015) Oriented Cell Division in the C. elegans Embryo Is Coordinated by G-Protein Signaling Dependent on the Adhesion GPCR LAT-1. PLoS Genet 11: e1005624 [PMID:26505631]

249. Naciff JM, Hess KA, Overmann GJ, Torontali SM, Carr GJ, Tiesman JP, Foertsch LM, Richardson 
BD, Martinez JE and Daston GP. (2005) Gene expression changes induced in the testis by transplacental exposure to high and low doses of 17 \{alpha\}-ethynyl estradiol, genistein, or bisphenol A. Toxicol Sci 86: 396-416 [PMID:15901920]

250. Naciff JM, Jump ML, Torontali SM, Carr GJ, Tiesman JP, Overmann GJ and Daston GP. (2002) Gene expression profile induced by 17alpha-ethynyl estradiol, bisphenol A, and genistein in the developing female reproductive system of the rat. Toxicol Sci 68: 184-99 [PMID:12075121]

251. Nagase T, Ishikawa K, Suyama M, Kikuno R, Miyajima N, Tanaka A, Kotani H, Nomura N and Ohara O. (1998) Prediction of the coding sequences of unidentified human genes. XI. The complete sequences of 100 new cDNA clones from brain which code for large proteins in vitro. DNA Res 5: 277-286 [PMID:9872452]

252. Nagase T, Seki N, Ishikawa K, Ohira M, Kawarabayasi Y, Ohara O, Tanaka A, Kotani H, Miyajima $\mathrm{N}$ and Nomura N. (1996) Prediction of the coding sequences of unidentified human genes. VI. The coding sequences of 80 new genes (KIAA0201-KIAA0280) deduced by analysis of cDNA clones from cell line KG-1 and brain. DNA Res 3: 321-9, 341-54 [PMID:9039502]

253. Nakayama J, Fu YH, Clark AM, Nakahara S, Hamano K, Iwasaki N, Matsui A, Arinami T and Ptácek LJ. (2002) A nonsense mutation of the MASS1 gene in a family with febrile and afebrile seizures. Ann Neurol 52: 654-7 [PMID:12402266]

254. Nakayama J, Hamano K, Iwasaki N, Nakahara S, Horigome Y, Saitoh H, Aoki T, Maki T, Kikuchi $\mathrm{M}$ and Migita T et al.. (2000) Significant evidence for linkage of febrile seizures to chromosome 5q14-q15. Hum Mol Genet 9: 87-91 [PMID:10587582]

255. Nakayama M, Nakajima D, Nagase T, Nomura N, Seki N and Ohara O. (1998) Identification of high-molecular-weight proteins with multiple EGF-like motifs by motif-trap screening. Genomics 51: 27-34 [PMID:9693030]

256. Nechiporuk T, Urness LD and Keating MT. (2001) ETL, a novel seven-transmembrane receptor that is developmentally regulated in the heart. ETL is a member of the secretin family and belongs to the epidermal growth factor-seven-transmembrane subfamily. J Biol Chem 276: 4150-7 [PMID:11050079]

257. Ni YY, Chen Y, Lu SY, Sun BY, Wang F, Wu XL, Dang SY, Zhang GH, Zhang HX and Kuang Y et al.. (2014) Deletion of Gpr128 results in weight loss and increased intestinal contraction frequency. World J Gastroenterol 20: 498-508 [PMID:24574718]

258. Nie T, Hui X, Gao X, Li K, Lin W, Xiang X, Ding M, Kuang Y, Xu A and Fei J et al.. (2012) Adipose tissue deletion of Gpr116 impairs insulin sensitivity through modulation of adipose function. FEBS Lett 586: 3618-25 [PMID:22971422]

259. Nikkila H, McMillan DR, Nunez BS, Pascoe L, Curnow KM and White PC. (2000) Sequence similarities between a novel putative $\mathrm{G}$ protein-coupled receptor and $\mathrm{Na}+/ \mathrm{Ca} 2+$ exchangers define a cation binding domain. Mol Endocrinol 14: 1351-64 [PMID:10976914]

260. Nishimori H, Shiratsuchi T, Urano T, Kimura Y, Kiyono K, Tatsumi K, Yoshida S, Ono M, Kuwano M, Nakamura Y and Tokino T. (1997) A novel brain-specific p53-target gene, BAI1, containing thrombospondin type 1 repeats inhibits experimental angiogenesis. Oncogene 15: 2145-2150 [PMID:9393972]

261. Nishimura T, Honda H and Takeichi M. (2012) Planar cell polarity links axes of spatial dynamics in neural-tube closure. Cell 149: 1084-97 [PMID:22632972]

262. Nordström KJ, Fredriksson R and Schiöth HB. (2008) The amphioxus (Branchiostoma floridae) genome contains a highly diversified set of $\mathrm{G}$ protein-coupled receptors. BMC Evol Biol 8: 9 [PMID:18199322]

263. O'Connell RM, Rao DS, Chaudhuri AA and Baltimore D. (2010) Physiological and pathological roles for microRNAs in the immune system. Nat Rev Immunol 10: 111-22 [PMID:20098459]

264. O'Sullivan ML, de Wit J, Savas JN, Comoletti D, Otto-Hitt S, Yates 3rd JR and Ghosh A. (2012) FLRT proteins are endogenous latrophilin ligands and regulate excitatory synapse development. Neuron 73: 903-10 [PMID:22405201]

265. Obermann H, Samalecos A, Osterhoff C, Schröder B, Heller R and Kirchhoff C. (2003) HE6, a two-subunit heptahelical receptor associated with apical membranes of efferent and epididymal duct epithelia. Mol Reprod Dev 64: 13-26 [PMID:12420295]

266. Oda K, Shiratsuchi T, Nishimori H, Inazawa J, Yoshikawa H, Taketani Y, Nakamura Y and Tokino T. (1999) Identification of BAIAP2 (BAI-associated protein 2), a novel human homologue of hamster IRSp53, whose SH3 domain interacts with the cytoplasmic domain of BAI1. Cytogenet Cell Genet 84: 75-82 [PMID:10343108]

267. Okajima D, Kudo G and Yokota H. (2010) Brain-specific angiogenesis inhibitor 2 (BAI2) may be activated by proteolytic processing. J Recept Signal Transduct Res 30: 143-53 [PMID:20367554]

268. Okajima D, Kudo G and Yokota H. (2011) Antidepressant-like behavior in brain-specific angiogenesis inhibitor 2-deficient mice.J Physiol Sci 61: 47-54 [PMID:21110148]

269. Okazaki N, F-Kikuno R, Ohara R, Inamoto S, Koseki H, Hiraoka S, Saga Y, Seino S, Nishimura M and Kaisho T et al.. (2004) Prediction of the coding sequences of mouse homologues of KIAA gene: IV. The complete nucleotide sequences of 500 mouse KIAA-homologous cDNAs identified by screening of terminal sequences of cDNA clones randomly sampled from size-fractionated 
libraries. DNA Res 11: 205-18 [PMID:15368895]

270. Osterhoff C, Ivell R and Kirchhoff C. (1997) Cloning of a human epididymis-specific mRNA, HE6, encoding a novel member of the seven transmembrane-domain receptor superfamily. DNA Cell Biol 16: 379-89 [PMID:9150425]

271. Ozkan A, Biçer A, Avşar T, Seker A, Toktaş ZO, Bozkurt SU, Başak AN and Kılıç T. (2012) Temporal expression analysis of angiogenesis-related genes in brain development. Vasc Cell 4: 16 [PMID:23020941]

272. Paavola KJ and Hall RA. (2012) Adhesion G protein-coupled receptors: signaling, pharmacology, and mechanisms of activation. Mol Pharmacol 82: 777-83 [PMID:22821233]

273. Paavola KJ, Sidik H, Zuchero JB, Eckart M and Talbot WS. (2014) Type IV collagen is an activating ligand for the adhesion G protein-coupled receptor GPR126. Sci Signal 7: ra76 [PMID:25118328]

274. Pagin A, Bergougnoux A, Girodon E, Reboul MP, Willoquaux C, Kesteloot M, Raynal C, Bienvenu T, Humbert M and Lalau G et al.. (2020) Novel ADGRG2 truncating variants in patients with Xlinked congenital absence of vas deferens. Andrology 8: 618-624 [PMID:31845523]

275. Park D, Tosello-Trampont AC, Elliott MR, Lu M, Haney LB, Ma Z, Klibanov AL, Mandell JW and Ravichandran KS. (2007) BAI1 is an engulfment receptor for apoptotic cells upstream of the ELMO/Dock180/Rac module. Nature 450: 430-4 [PMID:17960134]

276. Parrini E, Ferrari AR, Dorn T, Walsh CA and Guerrini R. (2009) Bilateral frontoparietal polymicrogyria, Lennox-Gastaut syndrome, and GPR56 gene mutations. Epilepsia 50: 1344-53 [PMID:19016831]

277. Patat O, Pagin A, Siegfried A, Mitchell V, Chassaing N, Faguer S, Monteil L, Gaston V, Bujan L and Courtade-Saïdi M et al.. (2016) Truncating Mutations in the Adhesion G Protein-Coupled Receptor G2 Gene ADGRG2 Cause an X-Linked Congenital Bilateral Absence of Vas Deferens. Am J Hum Genet 99: 437-42 [PMID:27476656]

278. Patra C, van Amerongen MJ, Ghosh S, Ricciardi F, Sajjad A, Novoyatleva T, Mogha A, Monk KR, Mühlfeld C and Engel FB. (2013) Organ-specific function of adhesion G protein-coupled receptor GPR126 is domain-dependent. Proc Natl Acad Sci USA 110: 16898-903 [PMID:24082093]

279. Peng YM, van de Garde MD, Cheng KF, Baars PA, Remmerswaal EB, van Lier RA, Mackay CR, Lin HH and Hamann J. (2011) Specific expression of GPR56 by human cytotoxic lymphocytes. $J$ Leukoc Biol 90: 735-40 [PMID:21724806]

280. Petersen SC, Luo R, Liebscher I, Giera S, Jeong SJ, Mogha A, Ghidinelli M, Feltri ML, Schöneberg T and Piao X et al.. (2015) The adhesion GPCR GPR126 has distinct, domaindependent functions in Schwann cell development mediated by interaction with laminin-211. Neuron 85: 755-69 [PMID:25695270]

281. Piao X, Chang BS, Bodell A, Woods K, Benzeev B, Topcu M, Guerrini R, Goldberg-Stern H, Sztriha L and Dobyns WB et al.. (2005) Genotype-phenotype analysis of human frontoparietal polymicrogyria syndromes. Ann Neurol 58: 680-7 [PMID:16240336]

282. Piao X, Hill RS, Bodell A, Chang BS, Basel-Vanagaite L, Straussberg R, Dobyns WB, Qasrawi B, Winter RM and Innes AM et al.. (2004) G protein-coupled receptor-dependent development of human frontal cortex. Science 303: 2033-6 [PMID:15044805]

283. Pickering C, Hägglund M, Szmydynger-Chodobska J, Marques F, Palha JA, Waller L, Chodobski A, Fredriksson R, Lagerström MC and Schiöth HB. (2008) The Adhesion GPCR GPR125 is specifically expressed in the choroid plexus and is upregulated following brain injury. $B M C$ Neurosci 9: 97 [PMID:18834514]

284. Ping YQ, Mao C, Xiao P, Zhao RJ, Jiang Y, Yang Z, An WT, Shen DD, Yang F and Zhang H et al.. (2021) Structures of the glucocorticoid-bound adhesion receptor GPR97- $\mathrm{G}_{0}$ complex. Nature 589: 620-626 [PMID:33408414]

285. Plager DA, Kahl JC, Asmann YW, Nilson AE, Pallanch JF, Friedman O and Kita H. (2010) Gene transcription changes in asthmatic chronic rhinosinusitis with nasal polyps and comparison to those in atopic dermatitis. PLOS ONE 5: e11450 [PMID:20625511]

286. Popova NV, Plotnikov A, Deev IE and Petrenko AG. (2007) Interaction of calcium-independent latrotoxin receptor with intracellular adapter protein TRIP8b. Dokl Biochem Biophys 414: 14951 [PMID:17695324]

287. Popova NV, Plotnikov AN, Ziganshin RKh, Deyev IE and Petrenko AG. (2008) Analysis of proteins interacting with TRIP8b adapter. Biochemistry Mosc 73: 644-51 [PMID:18620529]

288. Posokhova E, Shukla A, Seaman S, Volate S, Hilton MB, Wu B, Morris H, Swing DA, Zhou M and Zudaire E et al.. (2015) GPR124 functions as a WNT7-specific coactivator of canonical $\beta$-catenin signaling. Cell Rep 10: 123-30 [PMID:25558062]

289. Prömel S, Waller-Evans H, Dixon J, Zahn D, Colledge WH, Doran J, Carlton MB, Grosse J, Schöneberg T and Russ AP et al.. (2012) Characterization and functional study of a cluster of four highly conserved orphan adhesion-GPCR in mouse. Dev Dyn 241: 1591-602 [PMID:22837050]

290. Purcell RH, Toro C, Gahl WA and Hall RA. (2017) A disease-associated mutation in the adhesion GPCR BAI2 (ADGRB2) increases receptor signaling activity. Hum Mutat 38: 1751-1760 
[PMID:28891236]

291. Qian YM, Haino M, Kelly K and Song WC. (1999) Structural characterization of mouse CD97 and study of its specific interaction with the murine decay-accelerating factor (DAF, CD55). Immunology 98: 303-11 [PMID:10540231]

292. Qu Y, Glasco DM, Zhou L, Sawant A, Ravni A, Fritzsch B, Damrau C, Murdoch JN, Evans S, Pfaff SL, Formstone C, Goffinet AM, Chandrasekhar A and Tissir F. (2010) Atypical cadherins Celsr13 differentially regulate migration of facial branchiomotor neurons in mice. J Neurosci 30: 9392 401 [PMID:20631168]

293. Quattrocchi CC, Zanni G, Napolitano A, Longo D, Cordelli DM, Barresi S, Randisi F, Valente EM, Verdolotti T and Genovese E et al.. (2013) Conventional magnetic resonance imaging and diffusion tensor imaging studies in children with novel GPR56 mutations: further delineation of a cobblestone-like phenotype. Neurogenetics 14: 77-83 [PMID:23274687]

294. Rahman MA, Ashton AC, Meunier FA, Davletov BA, Dolly JO and Ushkaryov YA. (1999) Norepinephrine exocytosis stimulated by alpha-latrotoxin requires both external and stored $\mathrm{Ca} 2+$ and is mediated by latrophilin, G proteins and phospholipase C. Philos Trans $R$ Soc Lond, B, Biol Sci 354: 379-86 [PMID:10212487]

295. Raible F, Tessmar-Raible K, Arboleda E, Kaller T, Bork P, Arendt D and Arnone MI. (2006) Opsins and clusters of sensory G-protein-coupled receptors in the sea urchin genome. Dev Biol 300: 461-75 [PMID:17067569]

296. Ravenscroft G, Nolent F, Rajagopalan S, Meireles AM, Paavola KJ, Gaillard D, Alanio E, Buckland M, Arbuckle S and Krivanek M et al.. (2015) Mutations of GPR126 are responsible for severe arthrogryposis multiplex congenita. Am J Hum Genet 96: 955-61 [PMID:26004201]

297. Ravni A, Qu Y, Goffinet AM and Tissir F. (2009) Planar cell polarity cadherin Celsr1 regulates skin hair patterning in the mouse. J Invest Dermatol 129: 2507-9 [PMID:19357712]

298. Regard JB, Sato IT and Coughlin SR. (2008) Anatomical profiling of G protein-coupled receptor expression. Cell 135: 561-71 [PMID:18984166]

299. Reiners J, van Wijk E, Märker T, Zimmermann U, Jürgens K, te Brinke H, Overlack N, Roepman $\mathrm{R}$, Knipper $\mathrm{M}$ and Kremer $\mathrm{H}$ et al.. (2005) Scaffold protein harmonin (USH1C) provides molecular links between Usher syndrome type 1 and type 2. Hum Mol Genet 14: 3933-43 [PMID:16301216]

300. Ribasés M, Ramos-Quiroga JA, Sánchez-Mora C, Bosch R, Richarte V, Palomar G, Gastaminza X, Bielsa A, Arcos-Burgos M and Muenke M et al.. (2011) Contribution of LPHN3 to the genetic susceptibility to ADHD in adulthood: a replication study. Genes Brain Behav 10: 149-57 [PMID:21040458]

301. Richter GH, Fasan A, Hauer K, Grunewald TG, Berns C, Rössler S, Naumann I, Staege MS, Fulda S and Esposito I et al.. (2013) G-Protein coupled receptor 64 promotes invasiveness and metastasis in Ewing sarcomas through PGF and MMP1. J Pathol 230: 70-81 [PMID:23338946]

302. Robinson A, Escuin S, Doudney K, Vekemans M, Stevenson RE, Greene ND, Copp AJ and Stanier P. (2012) Mutations in the planar cell polarity genes CELSR1 and SCRIB are associated with the severe neural tube defect craniorachischisis. Hum Mutat 33: 440-7 [PMID:22095531]

303. Sabik OL, Calabrese GM, Taleghani E, Ackert-Bicknell CL and Farber CR. (2020) Identification of a Core Module for Bone Mineral Density through the Integration of a Co-expression Network and GWAS Data. Cell Rep 32: 108145 [PMID:32937138]

304. Sahly I, Dufour E, Schietroma C, Michel V, Bahloul A, Perfettini I, Pepermans E, Estivalet A, Carette D and Aghaie A et al.. (2012) Localization of Usher 1 proteins to the photoreceptor calyceal processes, which are absent from mice. J Cell Biol 199: 381-99 [PMID:23045546]

305. Salašová A, Yokota C, Potěšil D, Zdráhal Z, Bryja V and Arenas E. (2017) A proteomic analysis of LRRK2 binding partners reveals interactions with multiple signaling components of the WNT/PCP pathway. Mol Neurodegener 12: 54 [PMID:28697798]

306. Salzman GS, Ackerman SD, Ding C, Koide A, Leon K, Luo R, Stoveken HM, Fernandez CG, Tall GG and Piao X et al.. (2016) Structural Basis for Regulation of GPR56/ADGRG1 by Its Alternatively Spliced Extracellular Domains. Neuron 91: 1292-1304 [PMID:27657451]

307. Schaller E, Macfarlane AJ, Rupec RA, Gordon S, McKnight AJ and Pfeffer K. (2002) Inactivation of the F4/80 glycoprotein in the mouse germ line. Mol Cell Biol 22: 8035-43 [PMID:12391169]

308. Schebesta A, McManus S, Salvagiotto G, Delogu A, Busslinger GA and Busslinger M. (2007) Transcription factor Pax 5 activates the chromatin of key genes involved in B cell signaling, adhesion, migration, and immune function. Immunity 27: 49-63 [PMID:17658281]

309. Scholz N, Gehring J, Guan C, Ljaschenko D, Fischer R, Lakshmanan V, Kittel RJ and Langenhan T. (2015) The adhesion GPCR latrophilin/CIRL shapes mechanosensation. Cell Rep 11: 866-874 [PMID:25937282]

310. Seandel M, Falciatori I, Shmelkov SV, Kim J, James D and Rafii S. (2008) Niche players: spermatogonial progenitors marked by GPR125. Cell Cycle 7: 135-40 [PMID:18256534]

311. Seandel M, James D, Shmelkov SV, Falciatori I, Kim J, Chavala S, Scherr DS, Zhang F, Torres R and Gale NW et al.. (2007) Generation of functional multipotent adult stem cells from GPR125+ germline progenitors. Nature 449: 346-50 [PMID:17882221] 
312. Senger DR, Perruzzi CA, Papadopoulos-Sergiou A and Van de Water L. (1994) Adhesive properties of osteopontin: regulation by a naturally occurring thrombin-cleavage in close proximity to the GRGDS cell-binding domain. Mol Biol Cell 5: 565-74 [PMID:7522656]

313. Shashidhar S, Lorente G, Nagavarapu U, Nelson A, Kuo J, Cummins J, Nikolich K, Urfer R and Foehr ED. (2005) GPR56 is a GPCR that is overexpressed in gliomas and functions in tumor cell adhesion. Oncogene 24: 1673-82 [PMID:15674329]

314. Shi J, Zhang X, Wang S, Wang J, Du B, Wang Z, Liu M, Jiang W, Qian M and Ren H. (2016) Gpr97 is dispensable for metabolic syndrome but is involved in macrophage inflammation in high-fat diet-induced obesity in mice. Sci Rep 6: 24649 [PMID:27089991]

315. Shima Y, Copeland NG, Gilbert DJ, Jenkins NA, Chisaka O, Takeichi M and Uemura T. (2002) Differential expression of the seven-pass transmembrane cadherin genes Celsr1-3 and distribution of the Celsr2 protein during mouse development. Dev Dyn 223: 321-32 [PMID:11891983]

316. Shima Y, Kawaguchi SY, Kosaka K, Nakayama M, Hoshino M, Nabeshima Y, Hirano T and Uemura T. (2007) Opposing roles in neurite growth control by two seven-pass transmembrane cadherins. Nat Neurosci 10: 963-9 [PMID:17618280]

317. Shima Y, Kengaku M, Hirano T, Takeichi M and Uemura T. (2004) Regulation of dendritic maintenance and growth by a mammalian 7-pass transmembrane cadherin. Dev Cell 7: 205-16 [PMID:15296717]

318. Shiratsuchi T, Futamura M, Oda K, Nishimori H, Nakamura Y and Tokino T. (1998) Cloning and characterization of BAI-associated protein 1: a PDZ domain-containing protein that interacts with BAI1. Biochem Biophys Res Commun 247: 597-604 [PMID:9647739]

319. Shiratsuchi T, Nishimori H, Ichise H, Nakamura Y and Tokino T. (1997) Cloning and characterization of BAI2 and BAI3, novel genes homologous to brain-specific angiogenesis inhibitor 1 (BAI1). Cytogenet Cell Genet 79: 103-8 [PMID:9533023]

320. Shiratsuchi T, Oda K, Nishimori H, Suzuki M, Takahashi E, Tokino T and Nakamura Y. (1998) Cloning and characterization of BAP3 (BAI-associated protein 3), a C2 domain-containing protein that interacts with BAI1. Biochem Biophys Res Commun 251: 158-65 [PMID:9790924]

321. Silva JP, Lelianova V, Hopkins C, Volynski KE and Ushkaryov Y. (2009) Functional crossinteraction of the fragments produced by the cleavage of distinct adhesion G-protein-coupled receptors. J Biol Chem 284: 6495-506 [PMID:19124473]

322. Silva JP, Lelianova VG, Ermolyuk YS, Vysokov N, Hitchen PG, Berninghausen O, Rahman MA, Zangrandi A, Fidalgo S and Tonevitsky AG et al.. (2011) Latrophilin 1 and its endogenous ligand Lasso/teneurin-2 form a high-affinity transsynaptic receptor pair with signaling capabilities. Proc Natl Acad Sci USA 108: 12113-8 [PMID:21724987]

323. Singer K, Luo R, Jeong SJ and Piao X. (2013) GPR56 and the developing cerebral cortex: cells, matrix, and neuronal migration. Mol Neurobiol 47: 186-96 [PMID:23001883]

324. Skradski SL, Clark AM, Jiang H, White HS, Fu YH and Ptácek LJ. (2001) A novel gene causing a mendelian audiogenic mouse epilepsy. Neuron 31: 537-544 [PMID:11545713]

325. Sleckman BP, Khan WN, Xu W, Bassing CH, Malynn BA, Copeland NG, Bardon CG, Breit TM, Davidson L and Oltz EM et al.. (2000) Cloning and functional characterization of the earlylymphocyte-specific Pb99 gene. Mol Cell Biol 20: 4405-10 [PMID:10825203]

326. St Croix B, Rago C, Velculescu V, Traverso G, Romans KE, Montgomery E, Lal A, Riggins GJ, Lengauer C and Vogelstein B et al.. (2000) Genes expressed in human tumor endothelium. Science 289: 1197-202 [PMID:10947988]

327. Stacey M, Chang GW, Davies JQ, Kwakkenbos MJ, Sanderson RD, Hamann J, Gordon S and Lin HH. (2003) The epidermal growth factor-like domains of the human EMR2 receptor mediate cell attachment through chondroitin sulfate glycosaminoglycans. Blood 102: 2916-24 [PMID:12829604]

328. Stacey M, Chang GW, Sanos SL, Chittenden LR, Stubbs L, Gordon S and Lin HH. (2002) EMR4, a novel epidermal growth factor (EGF)-TM7 molecule up-regulated in activated mouse macrophages, binds to a putative cellular ligand on B lymphoma cell line A20. J Biol Chem 277: 29283-93 [PMID:12023293]

329. Stacey M, Lin HH, Hilyard KL, Gordon S and McKnight AJ. (2001) Human epidermal growth factor (EGF) module-containing mucin-like hormone receptor 3 is a new member of the EGFTM7 family that recognizes a ligand on human macrophages and activated neutrophils. J Biol Chem 276: 18863-70 [PMID:11279179]

330. Stehlik C, Kroismayr R, Dorfleutner A, Binder BR and Lipp J. (2004) VIGR--a novel inducible adhesion family G-protein coupled receptor in endothelial cells. FEBS Lett 569: 149-55 [PMID:15225624]

331. Steinert M, Wobus M, Boltze C, Schütz A, Wahlbuhl M, Hamann J and Aust G. (2002) Expression and regulation of CD97 in colorectal carcinoma cell lines and tumor tissues. Am J Pathol 161: 1657-67 [PMID:12414513]

332. Stevens CF and Williams JH. (2000) "Kiss and run" exocytosis at hippocampal synapses. Proc Natl Acad Sci USA 97: 12828-33 [PMID:11050187] 
333. Stoveken HM, Bahr LL, Anders MW, Wojtovich AP, Smrcka AV and Tall GG. (2016) Dihydromunduletone Is a Small-Molecule Selective Adhesion G Protein-Coupled Receptor Antagonist. Mol Pharmacol 90: 214-24 [PMID:27338081]

334. Stoveken HM, Hajduczok AG, Xu L and Tall GG. (2015) Adhesion G protein-coupled receptors are activated by exposure of a cryptic tethered agonist. Proc Natl Acad Sci USA 112: 6194-9 [PMID:25918380]

335. Stoveken HM, Larsen SD, Smrcka AV and Tall GG. (2018) Gedunin- and Khivorin-Derivatives Are Small-Molecule Partial Agonists for Adhesion G Protein-Coupled Receptors GPR56/ADGRG1 and GPR114/ADGRG5. Mol Pharmacol 93: 477-488 [PMID:29476042]

336. Sugimura R, He XC, Venkatraman A, Arai F, Box A, Semerad C, Haug JS, Peng L, Zhong XB and Suda T et al.. (2012) Noncanonical Wnt signaling maintains hematopoietic stem cells in the niche. Cell 150: 351-65 [PMID:22817897]

337. Sugita S, Ichtchenko K, Khvotchev M and Südhof TC. (1998) alpha-Latrotoxin receptor CIRL/latrophilin 1 (CL1) defines an unusual family of ubiquitous G-protein-linked receptors. Gprotein coupling not required for triggering exocytosis. J Biol Chem 273: 32715-24 [PMID:9830014]

338. Sun P, He L, Jia K, Yue Z, Li S, Jin Y, Li Z, Siwko S, Xue F and Su J et al.. (2020) Regulation of body length and bone mass by Gpr126/Adgrg6. Sci Adv 6: eaaz0368 [PMID:32219165]

339. Suzuki G, Kanda Y, Nibuya M, Hiramoto T, Tanaka T, Shimizu K, Watanabe Y and Nomura S. (2007) Stress and electroconvulsive seizure differentially alter GPR56 expression in the adult rat brain. Brain Res 1183: 21-31 [PMID:17945200]

340. Tang X, Jin R, Qu G, Wang X, Li Z, Yuan Z, Zhao C, Siwko S, Shi T and Wang P et al.. (2013) GPR116, an adhesion G-protein-coupled receptor, promotes breast cancer metastasis via the Goq-p63RhoGEF-Rho GTPase pathway. Cancer Res 73: 6206-18 [PMID:24008316]

341. Tarpey PS, Smith R, Pleasance E, Whibley A, Edkins S, Hardy C, O'Meara S, Latimer C, Dicks E and Menzies A et al.. (2009) A systematic, large-scale resequencing screen of X-chromosome coding exons in mental retardation. Nat Genet 41: 535-43 [PMID:19377476]

342. Terskikh AV, Easterday MC, Li L, Hood L, Kornblum HI, Geschwind DH and Weissman IL. (2001) From hematopoiesis to neuropoiesis: evidence of overlapping genetic programs. Proc Natl Acad Sci USA 98: 7934-9 [PMID:11438738]

343. Thakar S, Wang L, Yu T, Ye M, Onishi K, Scott J, Qi J, Fernandes C, Han X and Yates 3rd JR et al.. (2017) Evidence for opposing roles of Celsr3 and Vangl2 in glutamatergic synapse formation. Proc Natl Acad Sci USA 114: E610-E618 [PMID:28057866]

344. Tissir F, Bar I, Jossin Y, De Backer O and Goffinet AM. (2005) Protocadherin Celsr3 is crucial in axonal tract development. Nat Neurosci 8: 451-7 [PMID:15778712]

345. Tissir F, De-Backer O, Goffinet AM and Lambert de Rouvroit C. (2002) Developmental expression profiles of Celsr (Flamingo) genes in the mouse. Mech Dev 112: 157-60 [PMID:11850187]

346. Tissir F and Goffinet AM. (2006) Expression of planar cell polarity genes during development of the mouse CNS. Eur J Neurosci 23: 597-607 [PMID:16487141]

347. Tissir F, Qu Y, Montcouquiol M, Zhou L, Komatsu K, Shi D, Fujimori T, Labeau J, Tyteca D, Courtoy P, Poumay Y, Uemura T and Goffinet AM. (2010) Lack of cadherins Celsr2 and Celsr3 impairs ependymal ciliogenesis, leading to fatal hydrocephalus. Nat Neurosci 13: 700-7 [PMID:20473291]

348. Tobaben S, Südhof TC and Stahl B. (2002) Genetic analysis of alpha-latrotoxin receptors reveals functional interdependence of CIRL/latrophilin 1 and neurexin 1 alpha. J Biol Chem 277: 635965 [PMID:11741895]

349. Towner RA, Jensen RL, Colman H, Vaillant B, Smith N, Casteel R, Saunders D, Gillespie DL, Silasi-Mansat R and Lupu F et al.. (2013) ELTD1, a potential new biomarker for gliomas. Neurosurgery 72: 77-90; discussion 91 [PMID:23096411]

350. Truong KL, Schlickeiser S, Vogt K, Boës D, Stanko K, Appelt C, Streitz M, Grütz G, Stobutzki N and Meisel C et al.. (2019) Killer-like receptors and GPR56 progressive expression defines cytokine production of human CD4 ${ }^{+}$memory T cells. Nat Commun 10: 2263 [PMID:31118448]

351. Tönjes A, Koriath M, Schleinitz D, Dietrich K, Böttcher Y, Rayner NW, Almgren P, Enigk B, Richter O, Rohm S, Fischer-Rosinsky A, Pfeiffer A, Hoffmann K, Krohn K, Aust G, Spranger J, Groop L, Blüher M, Kovacs P and Stumvoll M. (2009) Genetic variation in GPR133 is associated with height: genome wide association study in the self-contained population of Sorbs. Hum Mol Genet 18: 4662-8 [PMID:19729412]

352. Urano T, Shiraki M, Yagi H, Ito M, Sasaki N, Sato M, Ouchi Y and Inoue S. (2012) GPR98/Gpr98 gene is involved in the regulation of human and mouse bone mineral density. J Clin Endocrinol Metab 97: E565-74 [PMID:22419726]

353. Usui T, Shima Y, Shimada Y, Hirano S, Burgess RW, Schwarz TL, Takeichi M and Uemura T. (1999) Flamingo, a seven-pass transmembrane cadherin, regulates planar cell polarity under the control of Frizzled. Cell 98: 585-95 [PMID:10490098]

354. Vakonakis I, Langenhan T, Prömel S, Russ A and Campbell ID. (2008) Solution structure and 
sugar-binding mechanism of mouse latrophilin-1 RBL: a 7TM receptor-attached lectin-like domain. Structure 16: 944-53 [PMID:18547526]

355. Vallon M, Aubele P, Janssen KP and Essler M. (2012) Thrombin-induced shedding of tumour endothelial marker 5 and exposure of its RGD motif are regulated by cell-surface protein disulfide-isomerase. Biochem J 441: 937-44 [PMID:22013897]

356. Vallon M and Essler M. (2006) Proteolytically processed soluble tumor endothelial marker (TEM) 5 mediates endothelial cell survival during angiogenesis by linking integrin alpha(v)beta3 to glycosaminoglycans. J Biol Chem 281: 34179-88 [PMID:16982628]

357. Vallon M, Rohde F, Janssen KP and Essler M. (2010) Tumor endothelial marker 5 expression in endothelial cells during capillary morphogenesis is induced by the small GTPase Rac and mediates contact inhibition of cell proliferation. Exp Cell Res 316: 412-21 [PMID:19853600]

358. Vallon M, Yuki K, Nguyen TD, Chang J, Yuan J, Siepe D, Miao Y, Essler M, Noda M and Garcia KC et al.. (2018) A RECK-WNT7 Receptor-Ligand Interaction Enables Isoform-Specific Regulation of Wnt Bioavailability. Cell Rep 25: 339-349.e9 [PMID:30304675]

359. van Eijk M, Aust G, Brouwer MS, van Meurs M, Voerman JS, Dijke IE, Pouwels W, Sändig I, Wandel E, Aerts JM, Boot RG, Laman JD and Hamann J. (2010) Differential expression of the EGF-TM7 family members CD97 and EMR2 in lipid-laden macrophages in atherosclerosis, multiple sclerosis and Gaucher disease. Immunol Lett 129: 64-71 [PMID:20167235]

360. van Pel M, Hagoort H, Hamann J and Fibbe WE. (2008) CD97 is differentially expressed on murine hematopoietic stem-and progenitor-cells. Haematologica 93: 1137-44 [PMID:18603564]

361. van Wijk E, van der Zwaag B, Peters T, Zimmermann U, Te Brinke H, Kersten FF, Märker T, Aller E, Hoefsloot LH and Cremers CW et al.. (2006) The DFNB31 gene product whirlin connects to the Usher protein network in the cochlea and retina by direct association with USH2A and VLGR1. Hum Mol Genet 15: 751-65 [PMID:16434480]

362. Vanhollebeke B, Stone OA, Bostaille N, Cho C, Zhou Y, Maquet E, Gauquier A, Cabochette P, Fukuhara S and Mochizuki N et al.. (2015) Tip cell-specific requirement for an atypical Gpr124and Reck-dependent Wnt/ß-catenin pathway during brain angiogenesis. Elife 4 [PMID:26051822]

363. Vanti WB, Nguyen T, Cheng R, Lynch KR, George SR and O'Dowd BF. (2003) Novel human Gprotein-coupled receptors. Biochem Biophys Res Commun 305: 67-71 [PMID:12732197]

364. Vassilatis DK, Hohmann JG, Zeng H, Li F, Ranchalis JE, Mortrud MT, Brown A, Rodriguez SS, Weller JR and Wright AC et al.. (2003) The G protein-coupled receptor repertoires of human and mouse. Proc Natl Acad Sci USA 100: 4903-8 [PMID:12679517]

365. Veninga H, Becker S, Hoek RM, Wobus M, Wandel E, van der Kaa J, van der Valk M, de Vos AF, Haase $\mathrm{H}$ and Owens B et al.. (2008) Analysis of CD97 expression and manipulation: antibody treatment but not gene targeting curtails granulocyte migration. J Immunol 181: 6574-83 [PMID:18941248]

366. Veninga H, Hoek RM, de Vos AF, de Bruin AM, An FQ, van der Poll T, van Lier RA, Medof ME and Hamann J. (2011) A novel role for CD55 in granulocyte homeostasis and anti-bacterial host defense. PLoS ONE 6: e24431 [PMID:21984892]

367. Vilboux T, Malicdan MC, Roney JC, Cullinane AR, Stephen J, Yildirimli D, Bryant J, Fischer R, Vemulapalli M and Mullikin JC et al.. (2017) CELSR2, encoding a planar cell polarity protein, is a putative gene in Joubert syndrome with cortical heterotopia, microophthalmia, and growth hormone deficiency. Am J Med Genet A 173: 661-666 [PMID:28052552]

368. Visser L, de Vos AF, Hamann J, Melief MJ, van Meurs M, van Lier RA, Laman JD and Hintzen RQ. (2002) Expression of the EGF-TM7 receptor CD97 and its ligand CD55 (DAF) in multiple sclerosis. J Neuroimmunol 132: 156-63 [PMID:12417446]

369. Volynski KE, Capogna M, Ashton AC, Thomson D, Orlova EV, Manser CF, Ribchester RR and Ushkaryov YA. (2003) Mutant alpha-latrotoxin (LTXN4C) does not form pores and causes secretion by receptor stimulation: this action does not require neurexins. J Biol Chem 278: 31058-66 [PMID:12782639]

370. Volynski KE, Silva JP, Lelianova VG, Atiqur Rahman M, Hopkins C and Ushkaryov YA. (2004) Latrophilin fragments behave as independent proteins that associate and signal on binding of LTX(N4C). EMBO J 23: 4423-33 [PMID:15483624]

371. Waller-Evans H, Prömel S, Langenhan T, Dixon J, Zahn D, Colledge WH, Doran J, Carlton MB, Davies B and Aparicio SA et al.. (2010) The orphan adhesion-GPCR GPR126 is required for embryonic development in the mouse. PLoS ONE 5: e14047 [PMID:21124978]

372. Wallgard E, Larsson E, He L, Hellström M, Armulik A, Nisancioglu MH, Genove G, Lindahl P and Betsholtz C. (2008) Identification of a core set of 58 gene transcripts with broad and specific expression in the microvasculature. Arterioscler Thromb Vasc Biol 28: 1469-76 [PMID:18483404]

373. Wallis D, Hill DS, Mendez IA, Abbott LC, Finnell RH, Wellman PJ and Setlow B. (2012) Initial characterization of mice null for Lphn3, a gene implicated in ADHD and addiction. Brain Res 1463: 85-92 [PMID:22575564]

374. Wandel E, Saalbach A, Sittig D, Gebhardt C and Aust G. (2012) Thy-1 (CD90) is an interacting 
partner for CD97 on activated endothelial cells. J Immunol 188: 1442-50 [PMID:22210915]

375. Wang JJ, Zhang LL, Zhang HX, Shen CL, Lu SY, Kuang Y, Wan YH, Wang WG, Yan HM and Dang SY et al.. (2013) Gpr97 is essential for the follicular versus marginal zone B-lymphocyte fate decision. Cell Death Dis 4: e853 [PMID:24113187]

376. Wang S, Mandell JD, Kumar Y, Sun N, Morris MT, Arbelaez J, Nasello C, Dong S, Duhn C and Zhao X et al.. (2018) De Novo Sequence and Copy Number Variants Are Strongly Associated with Tourette Disorder and Implicate Cell Polarity in Pathogenesis. Cell Rep 24: 3441-3454.e12 [PMID:30257206]

377. Wang T, Tian L, Haino M, Gao JL, Lake R, Ward Y, Wang H, Siebenlist U, Murphy PM and Kelly K. (2007) Improved antibacterial host defense and altered peripheral granulocyte homeostasis in mice lacking the adhesion class G protein receptor CD97. Infect Immun 75: 1144-53 [PMID:17158902]

378. Wang T, Ward Y, Tian L, Lake R, Guedez L, Stetler-Stevenson WG and Kelly K. (2005) CD97, an adhesion receptor on inflammatory cells, stimulates angiogenesis through binding integrin counterreceptors on endothelial cells. Blood 105: 2836-44 [PMID:15576472]

379. Ward Y, Lake R, Martin PL, Killian K, Salerno P, Wang T, Meltzer P, Merino M, Cheng SY and Santoro M et al.. (2013) CD97 amplifies LPA receptor signaling and promotes thyroid cancer progression in a mouse model. Oncogene 32: 2726-38 [PMID:22797060]

380. Ward Y, Lake R, Yin JJ, Heger CD, Raffeld M, Goldsmith PK, Merino M and Kelly K. (2011) LPA receptor heterodimerizes with CD97 to amplify LPA-initiated RHO-dependent signaling and invasion in prostate cancer cells. Cancer Res 71: 7301-11 [PMID:21978933]

381. Weston MD, Luijendijk MW, Humphrey KD, Möller C and Kimberling WJ. (2004) Mutations in the VLGR1 gene implicate G-protein signaling in the pathogenesis of Usher syndrome type II. Am J Hum Genet 74: 357-66 [PMID:14740321]

382. White GR, Varley JM and Heighway J. (1998) Isolation and characterization of a human homologue of the latrophilin gene from a region of 1p31.1 implicated in breast cancer. Oncogene 17: 3513-9 [PMID:10030676]

383. Wilde C, Fischer L, Lede V, Kirchberger J, Rothemund S, Schöneberg T and Liebscher I. (2016) The constitutive activity of the adhesion GPCR GPR114/ADGRG5 is mediated by its tethered agonist. FASEB J 30: 666-73 [PMID:26499266]

384. Willsey AJ, Fernandez TV, Yu D, King RA, Dietrich A, Xing J, Sanders SJ, Mandell JD, Huang AY and Richer P et al.. (2017) De Novo Coding Variants Are Strongly Associated with Tourette Disorder. Neuron 94: 486-499.e9 [PMID:28472652]

385. Wobus M, Vogel B, Schmücking E, Hamann J and Aust G. (2004) N-glycosylation of CD97 within the EGF domains is crucial for epitope accessibility in normal and malignant cells as well as CD55 ligand binding. Int J Cancer 112: 815-22 [PMID:15386373]

386. Wu H, Gao Y, Ma C, Shen Q, Wang J, Lv M, Liu C, Cheng H, Zhu F and Tian S et al.. (2020) A novel hemizygous loss-of-function mutation in ADGRG2 causes male infertility with congenital bilateral absence of the vas deferens. J Assist Reprod Genet 37: 1421-1429 [PMID:32314195]

387. Wu J, Lei L, Wang S, Gu D and Zhang J. (2012) Immunohistochemical expression and prognostic value of CD97 and its ligand CD55 in primary gallbladder carcinoma. J Biomed Biotechnol 2012: 587672 [PMID:22547928]

388. Wu Q and Maniatis T. (2000) Large exons encoding multiple ectodomains are a characteristic feature of protocadherin genes. Proc Natl Acad Sci USA 97: 3124-9 [PMID:10716726]

389. Xiao J, Jiang H, Zhang R, Fan G, Zhang Y, Jiang D and Li H. (2012) Augmented cardiac hypertrophy in response to pressure overload in mice lacking ELTD1. PLoS ONE 7: e35779 [PMID:22606234]

390. Xu L, Begum S, Hearn JD and Hynes RO. (2006) GPR56, an atypical G protein-coupled receptor, binds tissue transglutaminase, TG2, and inhibits melanoma tumor growth and metastasis. Proc Natl Acad Sci USA 103: 9023-8 [PMID:16757564]

391. Xu L and Hynes RO. (2007) GPR56 and TG2: possible roles in suppression of tumor growth by the microenvironment. Cell Cycle 6: 160-5 [PMID:17314516]

392. Yagi H, Takamura Y, Yoneda T, Konno D, Akagi Y, Yoshida K and Sato M. (2005) Vlgr1 knockout mice show audiogenic seizure susceptibility. J Neurochem 92: 191-202 [PMID:15606908]

393. Yagi H, Tokano H, Maeda M, Takabayashi T, Nagano T, Kiyama H, Fujieda S, Kitamura K and Sato M. (2007) Vlgr1 is required for proper stereocilia maturation of cochlear hair cells. Genes Cells 12: 235-50 [PMID:17295842]

394. Yamada Y, Fuku N, Tanaka M, Aoyagi Y, Sawabe M, Metoki N, Yoshida H, Satoh K, Kato K, Watanabe S, Nozawa Y, Hasegawa A and Kojima T. (2009) Identification of CELSR1 as a susceptibility gene for ischemic stroke in Japanese individuals by a genome-wide association study. Atherosclerosis 207: 144-9 [PMID:19403135]

395. Yamamoto Y, Irie K, Asada M, Mino A, Mandai K and Takai Y. (2004) Direct binding of the human homologue of the Drosophila disc large tumor suppressor gene to seven-pass transmembrane proteins, tumor endothelial marker 5 (TEM5), and a novel TEM5-like protein. Oncogene 23: 3889-97 [PMID:15021905] 
396. Yang J, Liu X, Zhao Y, Adamian M, Pawlyk B, Sun X, McMillan DR, Liberman MC and Li T. (2010) Ablation of whirlin long isoform disrupts the USH2 protein complex and causes vision and hearing loss. PLoS Genet 6: e1000955 [PMID:20502675]

397. Yang L, Chen G, Mohanty S, Scott G, Fazal F, Rahman A, Begum S, Hynes RO and Xu L. (2011) GPR56 Regulates VEGF production and angiogenesis during melanoma progression. Cancer Res 71: 5558-68 [PMID:21724588]

398. Yang MY, Hilton MB, Seaman S, Haines DC, Nagashima K, Burks CM, Tessarollo L, Ivanova PT, Brown HA and Umstead TM et al.. (2013) Essential regulation of lung surfactant homeostasis by the orphan G protein-coupled receptor GPR116. Cell Rep 3: 1457-64 [PMID:23684610]

399. Yates LL, Papakrivopoulou J, Long DA, Goggolidou P, Connolly JO, Woolf AS and Dean CH. (2010) The planar cell polarity gene Vangl2 is required for mammalian kidney-branching morphogenesis and glomerular maturation. Hum Mol Genet 19: 4663-76 [PMID:20843830]

400. Yates LL, Schnatwinkel C, Murdoch JN, Bogani D, Formstone CJ, Townsend S, Greenfield A, Niswander LA and Dean CH. (2010) The PCP genes Celsr1 and Vangl2 are required for normal lung branching morphogenesis. Hum Mol Genet 19: 2251-67 [PMID:20223754]

401. Ying G, Wu S, Hou R, Huang W, Capecchi MR and Wu Q. (2009) The protocadherin gene Celsr3 is required for interneuron migration in the mouse forebrain. Mol Cell Biol 29: 3045-61 [PMID:19332558]

402. Yona S, Lin HH, Dri P, Davies JQ, Hayhoe RP, Lewis SM, Heinsbroek SE, Brown KA, Perretti M and Hamann J et al.. (2008) Ligation of the adhesion-GPCR EMR2 regulates human neutrophil function. FASEB J 22: 741-51 [PMID:17928360]

403. Yona S, Lin HH, Siu WO, Gordon S and Stacey M. (2008) Adhesion-GPCRs: emerging roles for novel receptors. Trends Biochem Sci 33: 491-500 [PMID:18789697]

404. Zallocchi M, Delimont D, Meehan DT and Cosgrove D. (2012) Regulated vesicular trafficking of specific PCDH15 and VLGR1 variants in auditory hair cells. J Neurosci 32: 13841-59 [PMID:23035094]

405. Zallocchi M, Meehan DT, Delimont D, Rutledge J, Gratton MA, Flannery J and Cosgrove D. (2012) Role for a novel Usher protein complex in hair cell synaptic maturation. PLOS ONE 7: e30573 [PMID:22363448]

406. Zencir S, Ovee M, Dobson MJ, Banerjee M, Topcu Z and Mohanty S. (2011) Identification of brain-specific angiogenesis inhibitor 2 as an interaction partner of glutaminase interacting protein. Biochem Biophys Res Commun 411: 792-7 [PMID:21787750]

407. Zendman AJ, Cornelissen IM, Weidle UH, Ruiter DJ and van Muijen GN. (1999) TM7XN1, a novel human EGF-TM7-like cDNA, detected with mRNA differential display using human melanoma cell lines with different metastatic potential. FEBS Lett 446: 292-8 [PMID:10100861]

408. Zhang DL, Sun YJ, Ma ML, Wang YJ, Lin H, Li RR, Liang ZL, Gao Y, Yang Z and He DF et al.. (2018) Gq activity- and $\beta$-arrestin-1 scaffolding-mediated ADGRG2/CFTR coupling are required for male fertility. Elife 7 [PMID:29393851]

409. Zhang GJ, Chen TB, Connolly B, Lin SA, Hargreaves R, Vanko A, Bednar B, Macneil DJ, Sur C and Williams DL. (2009) In vivo optical imaging of LacZ expression using lacZ transgenic mice. Assay Drug Dev Technol 7: 391-9 [PMID:19689207]

410. Zhang H, Dong Y, Zhao H, Brooks JD, Hawthorn L, Nowak N, Marshall JR, Gao AC and Ip C. (2005) Microarray Data Mining for Potential Selenium Targets in Chemoprevention of Prostate Cancer. Cancer Genomics Proteomics 2: 97-114 [PMID:18548127]

411. Zhou L, Bar I, Achouri Y, Campbell K, De Backer O, Hebert JM, Jones K, Kessaris N, de Rouvroit CL, O'Leary D, Richardson WD, Goffinet AM and Tissir F. (2008) Early forebrain wiring: genetic dissection using conditional Celsr3 mutant mice. Science 320: 946-9 [PMID:18487195]

412. Zhou L, Qu Y, Tissir F and Goffinet AM. (2009) Role of the atypical cadherin Celsr3 during development of the internal capsule. Cereb Cortex 19 Suppl 1: i114-9 [PMID:19349379]

413. Zhou Y and Nathans J. (2014) Gpr124 controls CNS angiogenesis and blood-brain barrier integrity by promoting ligand-specific canonical wnt signaling. Dev Cell 31: 248-56 [PMID:25373781]

414. Zhu D, Hunter SB, Vertino PM and Van Meir EG. (2011) Overexpression of MBD2 in glioblastoma maintains epigenetic silencing and inhibits the antiangiogenic function of the tumor suppressor gene BAI1. Cancer Res 71: 5859-70 [PMID:21724586]

415. Zhu D, Osuka S, Zhang Z, Reichert ZR, Yang L, Kanemura Y, Jiang Y, You S, Zhang H and Devi NS et al.. (2018) BAI1 Suppresses Medulloblastoma Formation by Protecting p53 from Mdm2Mediated Degradation. Cancer Cell 33: 1004-1016.e5 [PMID:29894688]

416. Ziegler J, Pody R, Coutinho de Souza P, Evans B, Saunders D, Smith N, Mallory S, Njoku C, Dong Y and Chen $\mathrm{H}$ et al.. (2017) ELTD1, an effective anti-angiogenic target for gliomas: preclinical assessment in mouse GL261 and human G55 xenograft glioma models. Neurooncology 19: 175-185 [PMID:27416955]

417. Zou J, Luo L, Shen Z, Chiodo VA, Ambati BK, Hauswirth WW and Yang J. (2011) Whirlin replacement restores the formation of the USH2 protein complex in whirlin knockout photoreceptors. Invest Ophthalmol Vis Sci 52: 2343-51 [PMID:21212183] 
418. Zuko A, Oguro-Ando A, Post $H$, Taggenbrock RL, van Dijk RE, Altelaar AF, Heck AJ, Petrenko AG, van der Zwaag B and Shimoda Y et al.. (2016) Association of Cell Adhesion Molecules Contactin-6 and Latrophilin-1 Regulates Neuronal Apoptosis. Front Mol Neurosci 9: 143 [PMID:28018171] 